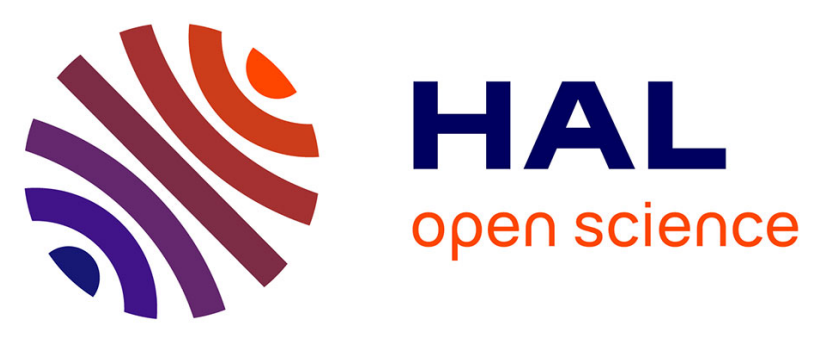

\title{
Date Palm Agrobiodiversity (Phoenix dactylifera L.) in Siwa Oasis, Egypt: Combining Ethnography, Morphometry, and Genetics
}

Vincent Battesti, Muriel Gros-Balthazard, Clémence Ogéron, Sarah Ivorra, Jean-Frederic Terral, Claire Newton

\section{To cite this version:}

Vincent Battesti, Muriel Gros-Balthazard, Clémence Ogéron, Sarah Ivorra, Jean-Frederic Terral, et al.. Date Palm Agrobiodiversity (Phoenix dactylifera L.) in Siwa Oasis, Egypt: Combining Ethnography, Morphometry, and Genetics. Human Ecology, 2018, 46 (4), pp.529-546. 10.1007/s10745-018-0006-y . hal-01716788

\section{HAL Id: hal-01716788 \\ https://hal.science/hal-01716788}

Submitted on 31 Aug 2018

HAL is a multi-disciplinary open access archive for the deposit and dissemination of scientific research documents, whether they are published or not. The documents may come from teaching and research institutions in France or abroad, or from public or private research centers.
L'archive ouverte pluridisciplinaire HAL, est destinée au dépôt et à la diffusion de documents scientifiques de niveau recherche, publiés ou non, émanant des établissements d'enseignement et de recherche français ou étrangers, des laboratoires publics ou privés.

\section{(ㅇ)(1) $\$$}

Distributed under a Creative Commons Attribution - NonCommercial - NoDerivatives 44.0 
Date Palm Agrobiodiversity (Phoenix dactylifera L.) in Siwa Oasis, Egypt:

Combining Ethnography, Morphometry, and Genetics

\section{Vincent Battesti, Muriel Gros-} Balthazard, Clémence Ogéron, Sarah Ivorra, Jean-Frédéric Terral \& Claire Newton

\section{Human Ecology}

An Interdisciplinary Journal

ISSN 0300-7839

Volume 46

Number 4

Hum Ecol (2018) 46:529-546

DOI 10.1007/s10745-018-0006-y

Battesti, Vincent, Muriel Gros-Balthazard, Clémence Ogéron, Sarah Ivorra, JeanFrédéric Terral \& Claire Newton, 2018 - « Date palm agrobiodiversity (Phoenix dactylifera L.) in Siwa oasis, Egypt : combining ethnography, morphometry, and genetics ». Human Ecology, 46 (4), p. 529-546 - online: https:// hal archives-ouvertes.fr/ hal-01716788

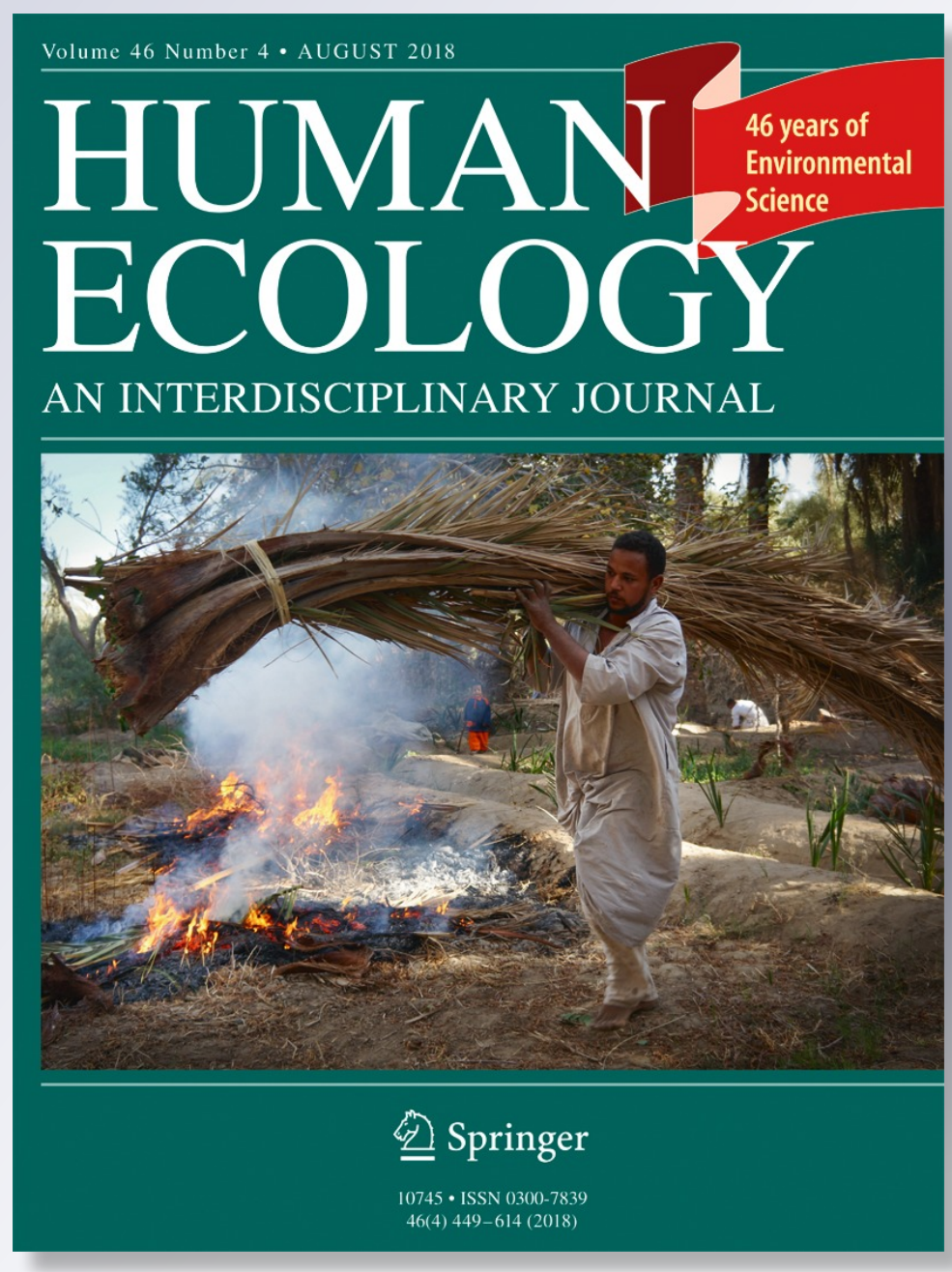

ill. cov.: In a Siwa oasis garden (Vincent Battesti) 算 Springer 


\title{
Date Palm Agrobiodiversity (Phoenix dactylifera L.) in Siwa Oasis, Egypt: Combining Ethnography, Morphometry, and Genetics
}

\author{
Vincent Battesti ${ }^{1}$ - Muriel Gros-Balthazard ${ }^{2,3} \cdot$ Clémence Ogéron $^{2} \cdot$ Sarah Ivorra $^{2} \cdot$ Jean-Frédéric Terral $^{2}$. \\ Claire Newton ${ }^{4}$
}

Published online: 20 June 2018

(C) Springer Science+Business Media, LLC, part of Springer Nature 2018

\begin{abstract}
We evaluate date palm (Phoenix dactylifera L.) agrobiodiversity of Siwa oasis, Egypt, located at the crossroads of ancient Trans-Saharan routes, focusing on diversity both as expressed and maintained by the folk categorization system of Siwa inhabitants (through an ethnographic analysis) and as described by genetic sciences and a morphometric tool based on size and geometry of seeds. We verified that some named types are true cultivars, sharing not only a formal identity, important for Isiwan people, but also a genetic identity. However, we also confirm the existence of "ethnovarieties," i.e., voluntary collections of multiple clones sharing phenotypic characteristics with the same local name, suggesting the genetic richness is higher than the apparent agrobiodiversity estimated by a superficial ethnobotanical approach. Finally, our research offers new insights on the relative importance of feral and cultivated date palms.
\end{abstract}

Keywords Agrobiodiversity · Date palm (Phoenix dactylifera L.) · Ethnographical analysis · Microsatellite markers $\cdot$ Seed morphometrics, Siwa Oasis, Egypt, Ethnovariety

"Of these [varieties of dates] we shall name some to give an idea of the extraordinary accuracy with which the oasis people distinguish the qualities

Vincent Battesti and Muriel Gros-Balthazard contributed equally to this work.

Electronic supplementary material The online version of this article (https://doi.org/10.1007/s10745-018-0006-y) contains supplementary material, which is available to authorized users.

Vincent Battesti

Vincent.Battesti@mnhn.fr

$1 \quad$ UMR 7206 Éco-anthropologie \& Ethnobiologie, CNRS \& Muséum National d'histoire Naturelle: Musée de l'Homme, 17 place du Trocadéro, 75016 Paris, France

2 Institut des Sciences de l'Évolution de Montpellier, UMR 5554 CNRS/Université de Montpellier/IRD/EPHE, CC065, Équipe Dynamique de la Biodiversité, Anthropo-écologie, Place Eugène Bataillon, 34095 Montpellier Cedex 5, France

3 Present address: Center for Genomics and Systems Biology, New York University Abu Dhabi, Abu Dhabi, UAE

4 Laboratoire d'archéologie et de patrimoine, Université du Québec à Rimouski, 300, allée des Ursulines, Rimouski (Québec) G5L 3AI, Canada according to taste, color, \&c., and how it occupies their minds and imaginations. It gives an insight into the spiritual life of the Orientals, and of the desert inhabitants in particular, and shows more than anything else the value of the date-palm." (Klee 1883: 13)

\section{Introduction}

Agrobiodiversity refers to the variability of animal, plant, and microbial organisms maintained by human societies. It is a major lever in coping with current and future challenges such as shifting environments, including the emergence of new diseases, climate change, and changing socioeconomic circumstances. Assessment and conservation of agrobiodiversity are therefore central to ensuring the continuing viability of agricultural production systems (Gepts et al. 2012). The cultivation of clonally propagated plants represents a singular system that has to date been largely neglected (McKey et al. 2010). 
The date palm (Phoenix dactylifera L.), grown for millennia around the Persian Gulf and in North Africa (Barrow 1998), constitutes the cornerstone of oasis agrosystems. ${ }^{1}$ These anthropogenic palm groves are most frequently groupings of private neighboring gardens that rely upon irrigated agriculture, classically intensive and characterized by mixed farming (Battesti 2005, 2012, 2015). However, some palm groves may be exploited only for dates, usually by nomadic pastoral populations who harvest and possibly also pollinate them (see Roué et al. 2015), as was the case of some groves near Siwa oasis. The iconic date palm (MichelDansac and Caubet 2013) has long been exploited not only for its fruit but also for many other uses (Battesti 2005), most importantly to create the "oasis effect," a bioclimatic bubble in the desert (Riou 1990). The origins of domestication, the routes and barriers of germplasm flows, and the breeding history within the traditional cultivation area are only partially known (Pintaud et al. 2013). Only a few populations of wild date palm, precursors to current cultivars, ${ }^{2}$ have recently been identified in Oman (Gros-Balthazard et al. 2017). The earliest evidence of date palm cultivation dates back to the third millennium BCE, around the Persian Gulf (Tengberg 2012). However, recent genetic and genomic data have pointed to the existence of two gene pools, indicating that domestication was probably a two-step process, first in the Middle East and secondarily in Africa (Hazzouri et al. 2015; Mathew et al. 2015; Gros-Balthazard et al. 2017).

Local populations selected numerous cultivars of date palms to meet their local and regional needs, and local soil and climate conditions, although it is impossible to accurately assess the number currently grown. A general survey indicates that more than 3000 cultivars probably exist (Zaid and Arias-Jiménez 1999), with likely more than 240 in Tunisia alone (Rhouma 1994, 2005). Nevertheless, some cases of homonymy (same name used in different localities for different genotypes) have already been noted in Egypt (El-Assar et al. 2005: 606), in Libya (Racchi et al. 2013), in Morocco (Bodian et al. 2014), and elsewhere (Popenoe and Bennett 1913;

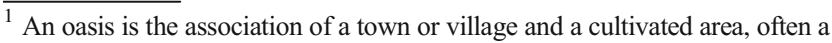
palm grove (of Phoenix dactylifera L.), around a water source in an otherwise arid or desert environment established, sometimes in the distant past, and maintained by local people (Battesti 2005, 2012).

2 "Cultivar" refers to a variety of clonal individuals, i.e., the association of a name and a single genotype reproduced vegetatively (asexually) by humans. For instance, all world-famous Deglet Noor date palms are presumed to derive from a single plant through the propagation of offshoots that ensures favorable genotypes, rather than sexual reproduction, which rarely produces equivalent or improved plants due to the highly heterozygous nature of their genomes. For further details on the dispute surrounding this issue see Popenoe and Bennett 1913: 44-56; Dowson and Aten 1962: 12-14; Peyron 2000: 23; Johnson et al. 2013: 812 .
}

Khanamm et al. 2012: 1240). Additionally, even though offshoot propagation is alleged to be a true-to-type technique (Jain 2012), genetic analyses have demonstrated that cultivars are not necessarily $100 \%$ identical (e.g., Medjool from Morocco; Elhoumaizi et al. 2006). Intracultivar genetic variability might exist due to somatic mutations (Devanand and Chao 2003; Gurevich et al. 2005; Abou Gabal et al. 2006; Elhoumaizi et al. 2006). Consequently, the notion of cultivar, resulting from social (a name) and agricultural (a genotype) work, remains debatable.

Our research is the first to offer an analytical and comprehensive focus on the agrobiodiversity of date palms in Siwa oasis. We contrast data from our ethnobotanical survey (Battesti 2013, see below) with data from genetic analyses and seed morphometrics. An ethnographic approach allows for accurate genetic and morphological interpretation: genetic analyses permit verification of relationships between the samples (Elhoumaizi et al. 2006; Bodian et al. 2014), and seed morphometric analyses quantify morphological diversity within and between named types (see Terral et al. 2012; Gros-Balthazard et al. 2016; Gros-Balthazard et al. 2017). The size and shape of seeds are indicators of the status of the plants as wild, feral, or cultivated, and vary between cultivars and species (Terral et al. 2012; Gros-Balthazard et al. 2016). The combination of morphometric and genetic analysis of samples from the same date palm allowed us to crosscheck our results and the local categorization of date palms collected through fieldwork. Ultimately, our objective was to obtain a better assessment of the local date palm categorization (Fig. 6).

\section{The Study Site}

Siwa oasis, Egypt, is located in the Libyan Desert $300 \mathrm{~km}$ south of the Mediterranean coast and the closest city Marsa Matruh, and about $70 \mathrm{~km}$ east of the present Libyan border (Fig. 1). Siwa refers to a small region of palm groves and settlements situated in a depression about $50 \mathrm{~km}$ long and $10 \mathrm{~km}$ wide, approximately $12 \mathrm{~m}$ below sea level, as well as its main town. Siwa oasis has been a major node in east-west and north-south Saharan trade routes between North Africa and the Nile Valley and the Middle East since at least the first millennium BCE (Kuhlmann 2013; Battesti in press). The vast majority of the population is Berberspeaking (Amazigh), with a minority of Shahibat Bedouin who settled over the last century in their own villages. According to the last Egyptian census (CAPMAS 2016), the current population is 33,000 and has been growing steadily over the last century $(22,000$ 


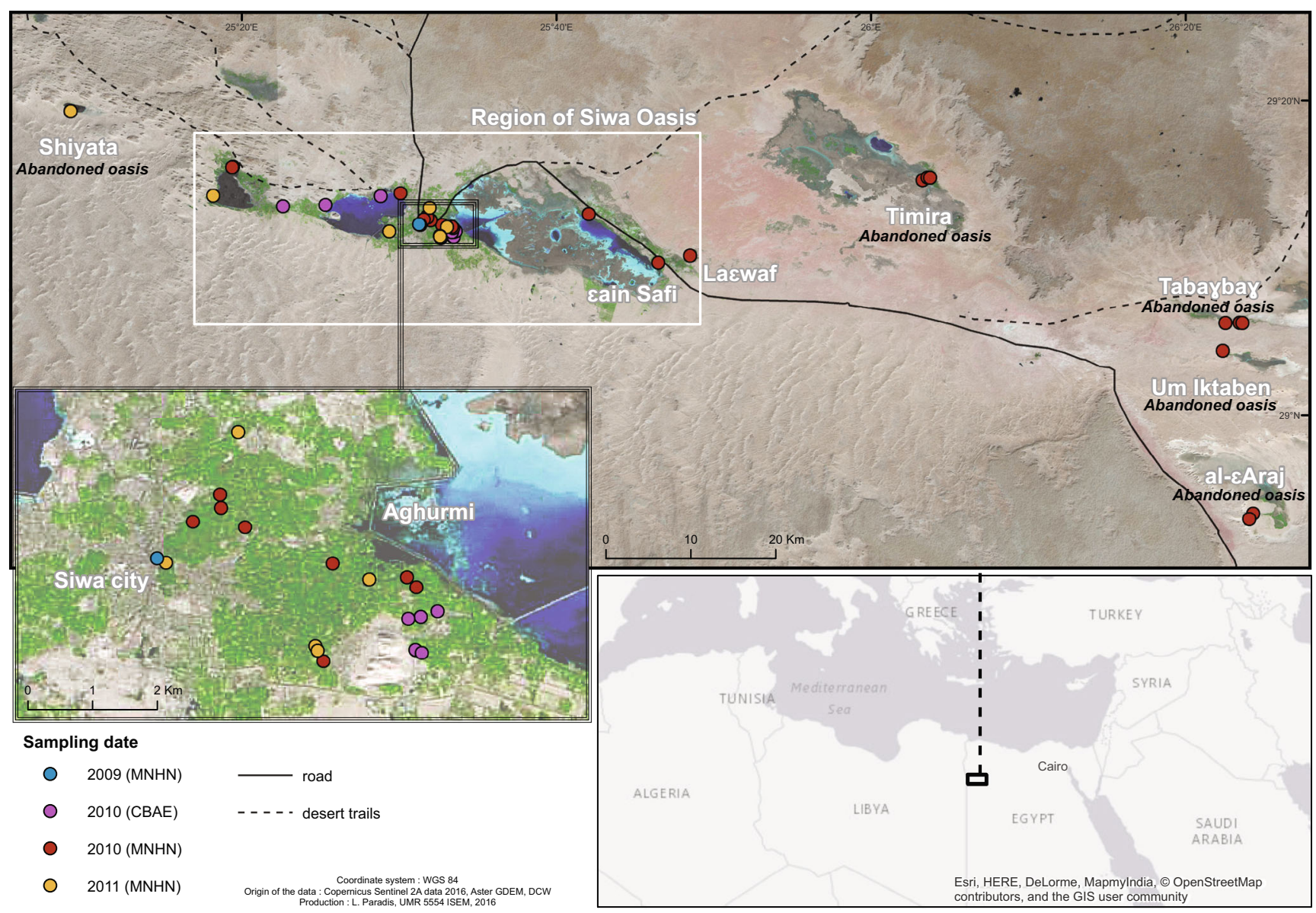

Fig. 1 Localization of the main geographic locations of the present study accessions

in 2006, 13,000 in 1996, and 3900 in 1907 (CAPMAS 2018). Nevertheless, compared to other oases the population is relatively small in relation to the cultivable and cultivated areas (Battesti 2005, 2006).

Despite the prime importance of date palms, which constitute the main cash crop, in the social and economic life of Siwa, little is known of their current or historical agrobiodiversity. We collated more than 60 references (travel accounts, newspaper articles, academic studies in geography, history, biology, etc.) published over the last two centuries mentioning local names of date palms from Siwa (Battesti 2013), but these typically use the vague term "variety," confusing local names of inclusive categories and cultivars. More recent surveys of the agrobiodiversity of the date palm in Egypt include only a few samples from Siwa (Adawy et al. 2005; Hussein et al. 2005). None of the three studies focused on date palm diversity in Siwa (Rizk and Rashed 2005; Abou Gabal et al. 2006; Abd El-Azeem et al. 2011) is comprehensive. Abou Gabal et al. (2006) interestingly concluded that intravarietal diversities exist in Siwa and explained them by somatic mutations. The prime issue for date palm biologists working on Siwa remains the identification of representative examples of a "cultivar:" the lack of an overview on how the different inclusive categories of date palms are named may lead to misinterpretation of the local agrobiodiversity.

In Siwa, the notion of cultivar is not explicitly expressed in the local Amazigh language. According to our ethnobotanical results (Battesti 2013), the agrobiodiversity of date palms in Siwa seems organized according to the notion of eškel, which refers to a "form" of date palm associated with a name and applies to any hierarchical level of categorization of date palms (see below). None of our informants ever tried to put a figure on date palm diversity. We also found that a single cultivar may bear different names and that some seedlings are also named (Battesti 2013). Consequently, as a result of the difficulty of compiling a comprehensive list (Fig. S1), our hypothetical overview of the date palm biodiversity of Siwa remains to be confirmed.

Ignoring different intermediate names, we concluded that there are about 15 different named types of date palms in Siwa (Battesti 2013) (Fig. S1). Simplifying a complex situation, we established that there are two locally favored cultivars, ${ }^{3}$ șacidi and alkak (also called frehi). Both keep and travel well owing to their low moisture and high sugar content: the semi-soft șaEidi is exported particularly to cities of the Nile Valley for

\footnotetext{
${ }^{3}$ Locally referred to as "the numbers 1 and 2" (nemra wahad we etnin).
} 
confectionery, and dry alkak are consumed by the Bedouin who transport the șąidi from Siwa (see below). A further seven alleged true-to-type cultivars are locally appreciated but less common: ayzāl, alkak wen žemb, lekrawmet, tatțagt, úšik niqbel, grom ayzāl, and yrom șacid.

An additional six named types are subject to some controversy: our informants all agreed on the fact that these date palms are reproduced vegetatively (cloned, as the "alleged true cultivars") but they did not all agree on the possibility that a seedling could also coincidentally produce one of these named types: halu en yanem, amenzu, úśik amayzuz, úšik ezzuway (or zuway), úšik azzugay, tažubart. These each meet the definition of an ethnovariety, i.e., a set of similar (according to local standards) lines of clones reproduced by offshoots under a single local name (Battesti 2013). ${ }^{4}$ To that, we must add two probable ethnovarieties: kacibī and úšik nekwayes. An ethnovariety differs from a landrace in that it is always reproduced vegetatively but might benefit from a seedling to create a new line of clones. According to Pintaud (2010: 109), a landrace of date palms is partially clonal or fully propagated by seed, but by consanguinity retaining a stable set of morphological traits. Thus, in the context of Siwa oasis, a landrace is composed of date palms growing untended, while an ethnovariety is cultivated. This can perhaps explain the genetic differences within a so-called single line of clones of a cultivar. These genetic differences have been reported in several studies as genetic variations at intravarietal levels, both for Siwa (Abou Gabal et al. 2006) and elsewhere (e.g., Morocco and Qatar: Bodian et al. 2012; Ahmed et al. 2013), which either propose the (convenient?) hypothesis of somatic mutations or fail to provide any explanation or connection with cultivation practices.

Finally, it is often assumed that date palm seedlings are merely accidental and rather ignored by local oasis farmers (Battesti 2005): uses of palm seedlings are yet to be thoroughly studied. In Siwa, it is very unusual to vegetatively multiply a male palm, ótem (Fig. S1). Most male date palm seedlings grow untended, usually outside the garden. A deliberately very low sex ratio is maintained (approximately $2 \%$ males) in the garden to favor female date palm trees. Accidental male seedlings are sufficient for pollination, provided that farmers artificially pollinate in place of the wind vector (Roué et al. 2015). In fact, male and female seedlings are a side-result of date palm agrobiodiversity, but are nonetheless an important gene pool. Locally, all farmers reproduce cultivated date palms through propagation using natural offshoots. Therefore, all seedlings occur as an indirect consequence of farmers cultivating their

\footnotetext{
$\overline{{ }^{4} \text { See Duputié }}$ et al.'s (2009) discussion of cassava (Manihot esculenta Crantz), where they define a landrace as a diverse assemblage of clones sharing, according to local farmers, phenotypic characteristics. To date, cassava is the only clonal crop for which in-depth information exists on how mixed clonal/sexual systems work (McKey et al. 2010). To the best of our knowledge, the only use of the term of ethnovariety is in relation to cassava (Raffaillac and Second 1997: 438; Second et al. 1999: 283).
}

progenitors. Usually, seedlings are discarded from the garden, but some nevertheless grow, and may even be pollinated and partly tended because, against all expectations, their fruits are good or they provide good quality fodder for the small domestic livestock. All female seedlings are called in Siwa $u ́ s ̌ i k-p l$. úškan. We refer to these female garden seedlings as úšik \#1 and those that grow untended outside the garden in the collective part of the palm grove or in its immediate periphery as úšik \#2.

We use the term "feral" date palms to refer to a population of uncultivated date palms growing spontaneously without human intervention even if their progenitors were formerly cultivated. Today, date palms from abandoned oases in the desert around Siwa reproduce freely by seed, i.e., sexually. In this study date palms outside the gardens (úšik \#2) may thus also be considered as feral but we describe them as "palm grove seedlings" (Table 1).

In sum, to address the complexities of assessing date palm agrobiodiversity in Siwa oasis we favor an overall multidisciplinary approach that takes into account local cultivation practices, knowledge, terminology, and categorization of date palms in combination with biological and ethnobotanical data.

\section{Materials and Methods}

\section{Plant Materials}

A total of 62 female date palms from in situ (private) gardens in palm groves or their periphery in and around Siwa oasis were sampled for leaflets and/or seeds (Table 1; Fig. 1). None of our specimens came from experimental stations. A palm grove is a mosaic of private cultivated gardens, generally with mixed farming (Battesti 2005) (Fig. 10). We sampled seeds for morphometric analyses and leaflets for genetic analyses. Two specimens were collected in 2009 (seeds only), and a total of 52 specimens (seeds and leaflets), during two different sampling drives (respectively six and 13 named types) during the fall of 2010. Sampling was completed in the fall of 2011 with 14 specimens (seeds and leaflets of six named types). Of our 62 samples, 32 belong to cultivated and named types (11), nine to garden seedlings (úšik \#1), seven to palm grove seedlings (úšik \#2), and 14 to desert feral date palms (from abandoned oases).

\section{Ethnobotanical Study}

Our team's social anthropologist and ethnobotanist conducted fieldwork between 2002 and 2015, including six months on date palm categorization and naming (for details see Battesti 2013). While he occasionally conducted structured interviews or held focus group discussions and free listings of date palm given names, most of his data derived from participant observation.

It is important to note that given local customs, he was generally restricted to contacts with men. However, with rare 
Table 1 Female date palm samples and the type they belong to. The status (feral, seedling or cultivated) and the location (Siwa oasis region or abandoned desert oases) are mentioned along with whether or not the sample was studied using seed morphometric and/or genetic

\begin{tabular}{|c|c|c|c|c|c|}
\hline ID & Type & Status & Location & Morphometric analysis & Genetic analysis \\
\hline 2048 & úšik \#1 & garden seedling & Siwa oasis & yes & yes \\
\hline 2049 & úšik \#1 & garden seedling & Siwa oasis & yes & yes \\
\hline 2051 & alkak & garden cultivated variety & Siwa oasis & yes & yes \\
\hline 2052 & tatțagt & garden cultivated variety & Siwa oasis & yes & yes \\
\hline 2054 & úšik \#2 & palm grove seedling & Siwa oasis & yes & yes \\
\hline 2055 & ayzāl & garden cultivated variety & Siwa oasis & yes & yes \\
\hline 2056 & úšik \#1 & garden seedling & Siwa oasis & yes & yes \\
\hline 2058 & úšik ezzuway & garden cultivated variety & Siwa oasis & yes & yes \\
\hline 2060 & úšik \#1 & garden seedling & Siwa oasis & yes & yes \\
\hline 2062 & úšik ezzuway & garden cultivated variety & Siwa oasis & yes & yes \\
\hline 2063 & úšik \#2 & palm grove seedling & Siwa oasis & yes & yes \\
\hline 2065 & yrom ayzāl & garden cultivated variety & Siwa oasis & yes & yes \\
\hline 2397 & kacibī & garden cultivated variety & Siwa oasis & yes & no \\
\hline 2398 & șąidi & garden cultivated variety & Siwa oasis & yes & yes \\
\hline 2399 & șąidi & garden cultivated variety & Siwa oasis & yes & yes \\
\hline 2400 & șąidi & garden cultivated variety & Siwa oasis & yes & yes \\
\hline 2401 & șazidi & garden cultivated variety & Siwa oasis & yes & yes \\
\hline 2402 & úšik \#1 & garden seedling & Siwa oasis & yes & yes \\
\hline 2403 & úšik \#1 & garden seedling & Siwa oasis & no & yes \\
\hline 2404 & sacidi & garden cultivated variety & Siwa oasis & yes & yes \\
\hline 2405 & tatțagt & garden cultivated variety & Siwa oasis & yes & yes \\
\hline 2406 & úšik nekwayes & garden cultivated variety & Siwa oasis & yes & yes \\
\hline 2407 & úšik \#1 & garden seedling & Siwa oasis & no & yes \\
\hline 2408 & alkak & garden cultivated variety & Siwa oasis & yes & no \\
\hline 2409 & ayzāl & garden cultivated variety & Siwa oasis & yes & yes \\
\hline 2410 & úšik amayzuz & garden cultivated variety & Siwa oasis & yes & yes \\
\hline 2411 & úšik \#1 & garden seedling & Siwa oasis & yes & yes \\
\hline 2412 & úšik ezzuway & garden cultivated variety & Siwa oasis & yes & yes \\
\hline 2413 & feral & desert feral & Um Iktaben & no & yes \\
\hline 2414 & feral & desert feral & al-EAraj & yes & yes \\
\hline 2415 & úšik \#1 & garden seedling & Siwa oasis & no & yes \\
\hline 2416 & alkak & garden cultivated variety & Siwa oasis & yes & yes \\
\hline 2417 & alkak wen žemb & garden cultivated variety & Siwa oasis & yes & yes \\
\hline 2418 & úšik \#2 & palm grove seedling & Siwa oasis & yes & yes \\
\hline 2419 & úšik ezzuway & garden cultivated variety & Siwa oasis & yes & yes \\
\hline 2420 & feral & desert feral & Um Iktaben & no & yes \\
\hline 2421 & feral & desert feral & al-عAraj & yes & yes \\
\hline 2422 & úšik niqbel & garden cultivated variety & Siwa oasis & yes & yes \\
\hline 2423 & úšik niqbel & garden cultivated variety & Siwa oasis & yes & yes \\
\hline 2424 & úšik \#2 & palm grove seedling & Siwa oasis & yes & yes \\
\hline 2425 & feral & desert feral & Tabaybay & yes & yes \\
\hline 2426 & feral & desert feral & Tabaybay & yes & yes \\
\hline 2427 & feral & desert feral & Tabaybay & yes & yes \\
\hline 2428 & feral & desert feral & Tabaybay & yes & yes \\
\hline 2429 & úšik \#2 & palm grove seedling & Siwa oasis & no & yes \\
\hline 2430 & feral & desert feral & Laعwāf & no & yes \\
\hline 2431 & feral & desert feral & Timira & yes & yes \\
\hline 2432 & feral & desert feral & Timira & yes & yes \\
\hline 2433 & feral & desert feral & Timira & yes & yes \\
\hline 3289 & șacidi & garden cultivated variety & Siwa oasis & yes & no \\
\hline 3290 & șacidi & garden cultivated variety & Siwa oasis & yes & no \\
\hline 3291 & șąidi & garden cultivated variety & Siwa oasis & yes & no \\
\hline 3292 & șąidi & garden cultivated variety & Siwa oasis & yes & no \\
\hline 3293 & alkak & garden cultivated variety & Siwa oasis & yes & no \\
\hline 3294 & yrom ayzāl & garden cultivated variety & Siwa oasis & yes & no \\
\hline 3295 & șazidi & garden cultivated variety & Siwa oasis & yes & no \\
\hline 3296 & úšik niqbel & garden cultivated variety & Siwa oasis & yes & no \\
\hline 3298 & șąidi & garden cultivated variety & Siwa oasis & yes & no \\
\hline 3299 & úšik \#2 & palm grove seedling & Siwa oasis & yes & no \\
\hline 3300 & úšik \#2 & palm grove seedling & Siwa oasis & yes & no \\
\hline 3301 & feral & desert feral & Shiyata & yes & no \\
\hline 3302 & feral & desert feral & Shiyata & yes & no \\
\hline
\end{tabular}


exceptions, only men have access to gardens and agricultural land in general. The investigator's few interactions with women revealed a much more superficial knowledge of agricultural issues and women's role in food preparation does not appear to influence the local categorization of dates.

\section{Genetic Analyses}

Total cellular DNA was extracted from dried leaves of 47 samples, which were then genotyped using 17 microsatellite loci (Table 2) following the protocol of Gros-Balthazard et al. (2017). The structure of genetic diversity of date palms in Siwa was assessed with a Principal Component Analysis (PCA) on gene frequencies using dudi.pca function (ade4 package; Dray and Dufour 2007) in R software (R Core Team 2015). A Neighbor-joining (NJ) tree was constructed with Nei's genetic distances (Nei et al. 1983) using aboot function in R (poppr package; Kamvar et al. 2014). The similarity between samples with the same given name was calculated as the average percentage of loci that are not polymorphic. We assumed that a collection of true-to-type clones is $100 \%$ similar except in case of somatic mutations.

\section{Morphometric Analysis of Seeds}

A total of 1100 seeds ( 20 per sample) from 55 accessions (Table 1) were analyzed using both traditional (size) and geometric (shape) morphometrics (Terral et al. 2012; Gros-Balthazard et al. 2016). Seeds were photographed in both dorsal and lateral views. Their length and width $(\mathrm{cm})$ on the dorsal side (following
Gros-Balthazard et al. 2016) were measured using ImageJ (Abràmoff et al. 2004). The shape of seeds was quantified using the Elliptic Fourier Transform (EFT) method (Kuhl and Giardina 1982) and implemented in R software (Momocs package; Bonhomme et al. 2014). To summarize, seed outline was extracted semi-automatically to obtain $x$ and $y$ coordinates of 64 points equally spaced along the outline of the seed. To avoid information redundancy and to standardize size and orientation, the coordinates were transformed using the EFT method leading to 32 harmonics, of which eight were retained (see Terral et al. 2012), with $A_{n}$ and $B_{n}$ related to $x$ coordinates, and $C_{n}$ and $D_{n}$ related to $y$ coordinates. The harmonic coefficients were used for subsequent statistical analyses in R.

The difference in seed size between the named types was tested using Tukey's test (function HSD.test, library agricolae). We appreciated the level of variability in both seed size and shape according to the protocol developed in GrosBalthazard et al. (2016). We first performed a Principal Component Analysis (PCA) on size or shape measurements and estimated the variation by calculating the size of the cloud valued as the mean distance between ten seeds from a given group randomly sampled and the centroid of that given group. We expected a true cultivar to show a reduced seed size variation while heterogeneous groups should have seeds of different sizes and shapes, and therefore show a high seed size or shape variation. We further explored the structure of seed morphotype diversity using a PCA performed using both discrete and outline measurements (function dudi.pca, package ade4). Additionally, we performed three Linear Discriminant Analyses (LDAs) on this full dataset to assess whether seed

Table 2 Overview of microsatellite loci

\begin{tabular}{|c|c|c|c|c|}
\hline Marker & Reference & Missing data & $\%$ Missing data & \# alleles \\
\hline mPdCIR085 & Billotte et al. 2004 & 0 & 0.00 & 10 \\
\hline mPdCIR078 & Billotte et al. 2004 & 1 & 1.06 & 11 \\
\hline mPdCIR015 & Billotte et al. 2004 & 30 & 31.92 & 4 \\
\hline mPdCIR016 & Billotte et al. 2004 & 1 & 1.06 & 5 \\
\hline mPdCIR032 & Billotte et al. 2004 & 4 & 4.26 & 6 \\
\hline mPdCIR035 & Billotte et al. 2004 & 0 & 0.00 & 3 \\
\hline mPdCIR057 & Billotte et al. 2004 & 0 & 0.00 & 6 \\
\hline mPdCIR025 & Billotte et al. 2004 & 2 & 2.13 & 8 \\
\hline mPdCIR010 & Billotte et al. 2004 & 4 & 4.26 & 8 \\
\hline mPdCIR063 & Billotte et al. 2004 & 4 & 4.26 & 6 \\
\hline mPdCIR050 & Billotte et al. 2004 & 2 & 2.13 & 10 \\
\hline PdAG1-ssr & Ludeña et al. 2011 & 1 & 1.06 & 12 \\
\hline PdCUC3-ssr1 & Zehdi-Azouzi et al. 2015 & 2 & 2.13 & 1 \\
\hline mPdIRD013 & Aberlenc-Bertossi et al. 2014 & 1 & 1.06 & 2 \\
\hline mPdIRD033 & Aberlenc-Bertossi et al. 2014 & 2 & 2.13 & 4 \\
\hline mPdIRD031 & Aberlenc-Bertossi et al. 2014 & 4 & 4.26 & 3 \\
\hline mPdIRD040 & Aberlenc-Bertossi et al. 2014 & 1 & 1.06 & 5 \\
\hline Overall & & 3.53 & 3.69 & 6.12 \\
\hline
\end{tabular}


size and shape allow, on the one hand, distinction of uncultivated date palms (desert feral and palm grove seedlings) from cultivated date palms (named types and garden seedlings), then desert feral date palms from garden named types and from seedlings growing either in palm groves or gardens; and on the other hand, to distinguish cultivars/named types from each other. We thus performed LDAs (lda function, package MASS) and used either factor "type" or "status" for the discrimination. To estimate the power of the LDAs, leave-one-out cross-validations were performed: posterior assignations were executed for each seed (option $\mathrm{CV}=\mathrm{T}$ ). The discriminating rate of each status or type was calculated as the percentage of positive allocation.

\section{Results}

\section{Patterns of Genetic Diversity in Siwa}

We genotyped 47 accessions using 17 microsatellite loci (SSRs). The percentage of missing data is low (Table 2), reflecting the efficiency of the microsatellite genotyping procedure. A total of 104 alleles were observed over the 17 SSRs, with an average of 6.12 per locus (Table 2).

\section{Overall Genetic Diversity}

Both the NJ tree (Fig. 2) and the PCA (Fig. 3) show a clear distinction between three named types (alkak, șacidi, tatțagt). The first component PC1 is stretched by alkak and tattagt while PC2 clearly separates the two main cultivars, namely șazidi and alkak (Fig. 3). Additionally, desert feral date palms are differentiated from úšik (both \#1 and \#2) and cultivated samples despite some overlap (Figs. 2 and 3).

The whole two-dimensional space shaped by $\mathrm{PC} 1$ and $\mathrm{PC} 2$ together seems organized by the combination of two important sets of fruit qualities: aqueous versus sweet and soft/semi-soft versus dry (Fig. 3). Indeed, alkak is sweet and dry, tattagt is aqueous and soft, and $a_{y} z \bar{a} l$, in the center of the graph, bears semi-soft and sweet dates. Those sets of qualities are important: date palms were first selected under these soil and climatic conditions for their fruits and to meet a variety of uses and tastes.

\section{Genetic Diversity in Cultivars, Ethnovarieties, and Other Categories}

Several named types are composed of accessions that appear very similar. For instance, șąidi accessions appear $96.97 \%$ similar (Table 5). Only two samples out of the five included show a single different allele over the 17 loci, and they all cluster together in the NJ tree (Fig. 2) and in the PCA plot (Fig. 3). Similarly, tattagt accessions from two different sampling drives are $100 \%$ similar. The two accessions of alkak also cluster together in both PCA and the NJ tree and are quite isolated from other accessions (Figs 2 and 3). However, they show three different alleles over 34 and are therefore very closely related but not perfect clones $(91.18 \%$, Table 5$)$. The alkak wen žemb sample is closely related to these two accessions in both PCA and the NJ tree (Figs. 2 and 3). Interestingly, farmers claim that alkak and alkak wen žemb are close relatives (wen žemb translates as "relegated," "put aside," i.e., a second class alkak). Locally, ayzāl and the very distantly related from ayzāl are considered closely related cultivars. ${ }^{5}$ However, further analyses are required to verify this.

Desert feral date palms form a large clade with a few exceptions, as three cultivated samples also group in this clade: tațtagt, úśik ezzuway and yrom ayzāl (Fig. 2). On the one hand, some geographical pattern seems at work as desert feral accessions from Tabaybay, an oasis uninhabited since Roman times, group together. On the other hand, desert feral accessions from the ancient oases of Timira, Um Iktaben, and al-£Araj, disseminated in the tree (Fig. 2, Table 1), seem less homogeneous. In ancient times, those locations were linked by desert routes: the main route from the eastern extremity of Siwa region, i.e., Eain Șafi, to the Bahariya oasis (and beyond to the Nile valley, Giza, and Cairo) ran through al-£Araj.

The seedling palms (úšik) cannot be distinguished as a group from cultivated date palms (Figs. 2 and 3) as they are scattered all over the distance tree, with garden seedlings úšik \#1 predominating within the clade of the named garden types (Fig. 2). The seedlings úšik \#1 and úšik \#2 are indistinguishable (Fig. 3).

\section{Characterization of Seed Size and Shape}

As expected in an uncultivated environment feral date palms show significantly smaller seeds than cultivated date palms (Tukey's test, $p$-value <0.05) (Gros-Balthazard et al. 2016) (Fig. 4). We evaluated the variation of seed size and shape for each named type (Table 3). Seeds from úšik \#1, úšik \#2 and desert feral samples have a very high variability in size and shape, since these palms grow in a diversity of conditions (size) and are not reproduced clonally (both size and shape), but rather are unrelated samples. On the other hand, șaidi and alkak, which are supposedly groups of cloned accessions (cultivars), display lower seed shape and size variability.

The PCA (Fig. 5) indicates that seeds of desert feral and úšik samples have a higher variability than the named garden types overall. Nonetheless, PC1 represents the variability of desert feral and úšik \#1 samples and PC2 that of cultivated named types (especially șąidi). PC3 is also mainly stretched by desert feral and úsik \#1 samples, and so the space PC2/PC3 slightly differentiates between úšik \#1 (benefiting from care) and úšik

\footnotetext{
${ }^{5}$ In local Amazigh, from derives from ayram (pl. iyarman), the seed.
} 
Fig. 2 Neighbor-Joining (NJ) tree of Siwa date palms based on $\mathrm{Nei}$ 1983 genetic distances

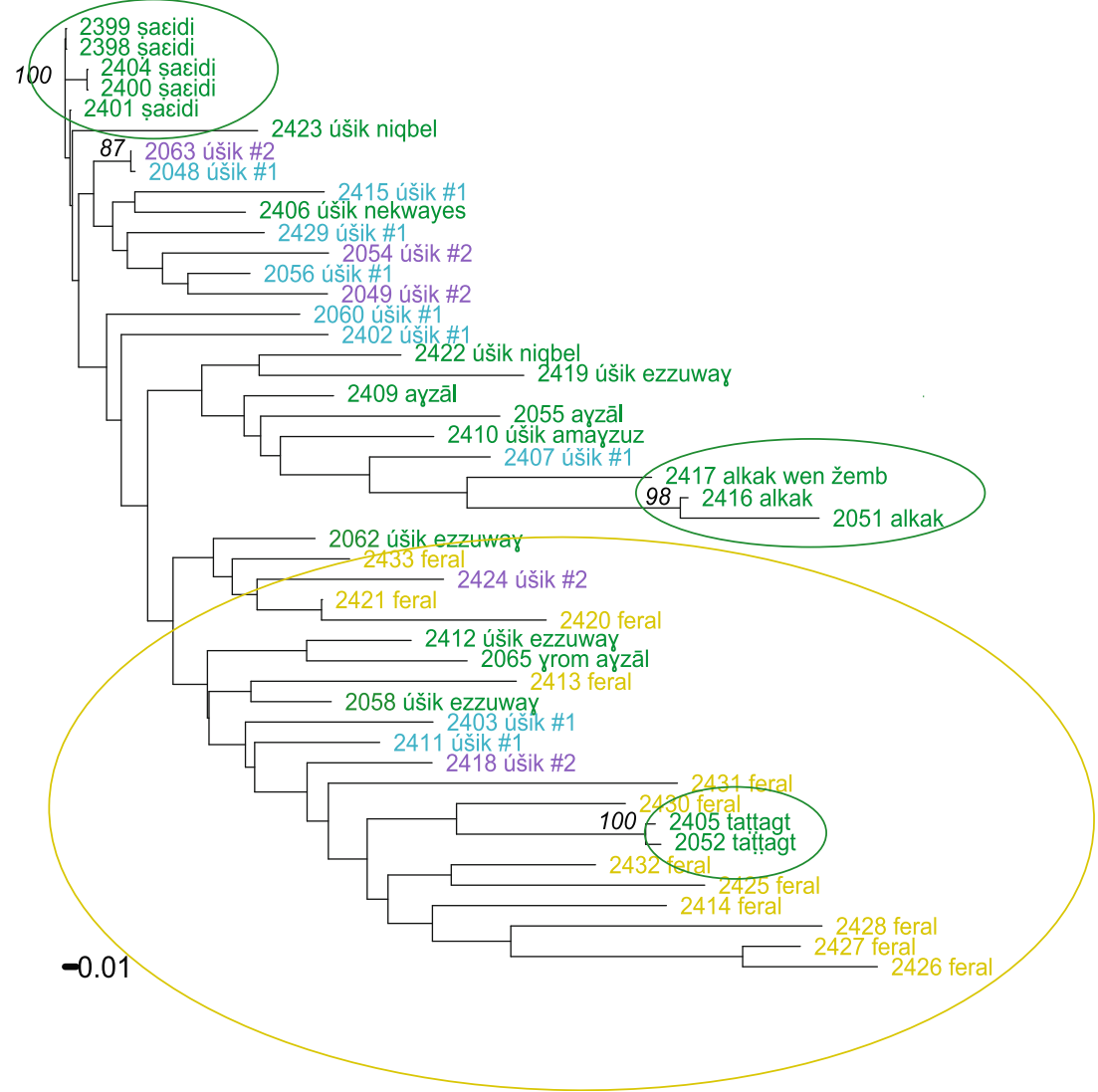

\#2 (untended) seedlings. Strangely enough, úšik \#1 offers in PCA the same wide and even wider dispersal in seed shape as the desert feral date palms. As regards the " $u$ śik xxx," i.e., the date palms with a given name including the word úšik-úšik niqbel, úšik nekwayes, úšik amayzuz, úšik ezzuway-their morphotypes roughly coincide with the other cultivated named types. They are locally said to be former $u ́ s ̌ i k$ as they are local seedlings selected as cultivars (in an unknown past) and vegetatively reproduced.

Using Linear Discriminant Analysis (LDA), we found that $90.1 \%$ of cultivated (garden cultivated varieties and $u ́ s i k \# 1$ ) and $79.2 \%$ of uncultivated (desert feral and úšik \#2) date palms were assigned positively to their status, meaning that

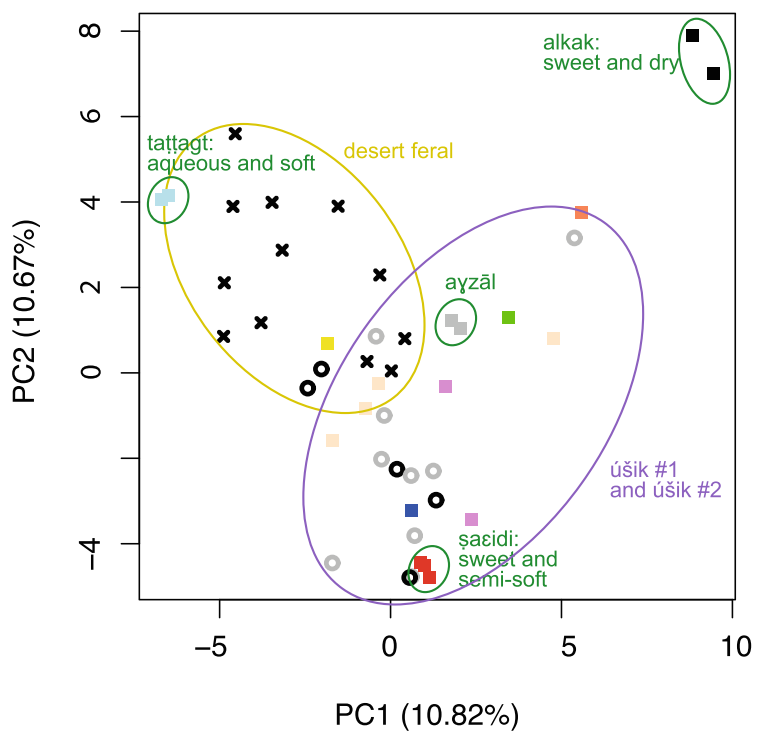

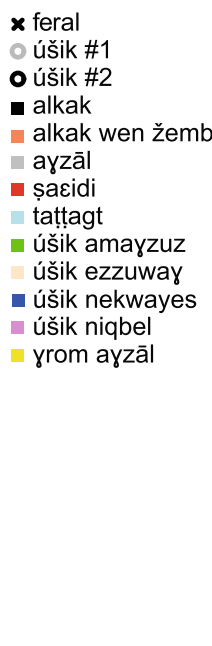

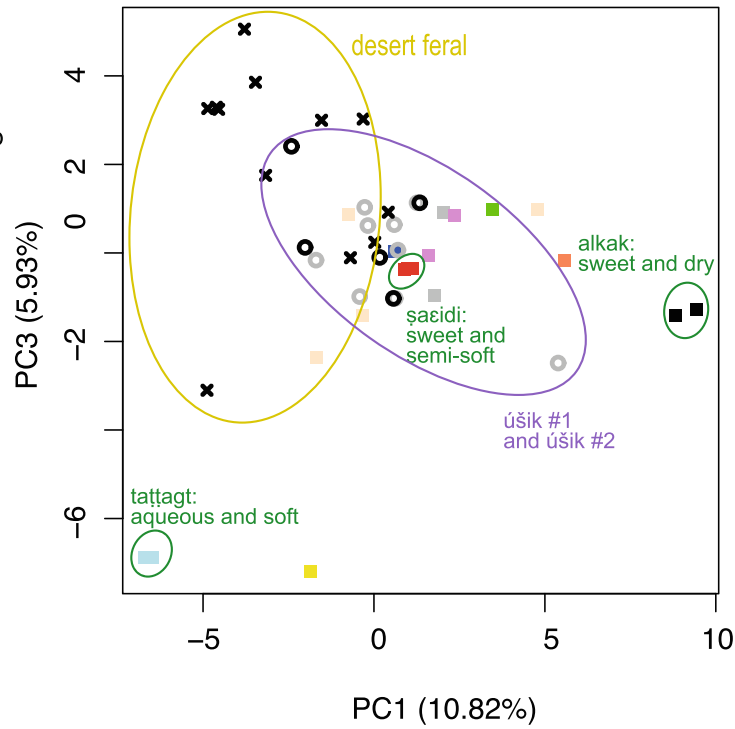

Fig. 3 Principal Component Analysis (PCA) on 48 date palm accessions using SSRs data 
Fig. 4 Seed size of Siwa date palms (mm). a Length, b Width. Letters below each box correspond to Tukey's group

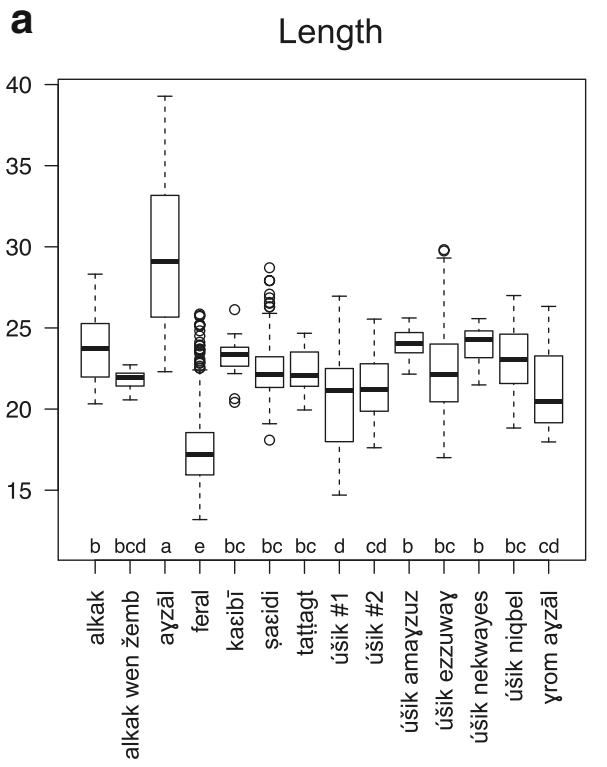

b

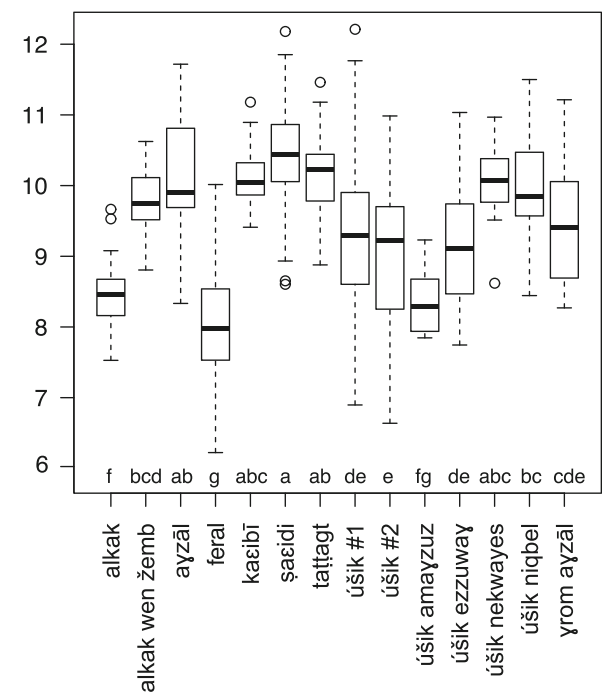

these two groups show highly divergent seeds and that within each group, seeds display particular features. A possible interpretation is that uncultivated seeds have a richer palette of shape as a local genetic pool. A further LDA test of three groups (feral (desert feral) vs. named types (garden cultivated varieties) vs. seedlings (úšik\#1 and úśik \#2)) found that $87.8 \%$ of named types, $78.8 \%$ of desert feral, and only $40.9 \%$ of

Table 3 Variability of seed dimensions and shape within named types of Siwa. It is calculated as the dispersion of seeds around the related species' centroid in two PCA spaces obtained from size parameters (Size Var.) and 64 Fourier coefficients related to dorsal and lateral seed shapes (Shape Var.) using the rarefaction method to balance sample size in each group. The values are the average over the mean distance between 10 randomly sampled seeds in one hundred replicates and the standard deviation over the one hundred replicates. The number of accessions available for each group is given (\# accessions). The groups derived from Tukey's test are given in parentheses

\begin{tabular}{|c|c|c|c|}
\hline Type & \# accessions & $\begin{array}{l}\text { Size var. } \\
\text { (Tukey's group) }\end{array}$ & $\begin{array}{l}\text { Shape var. } \\
\text { (Tukey's group) }\end{array}$ \\
\hline úšik \#1 & 6 & $83.88 \pm 21.56$ (a) & $761.22 \pm 211.41(\mathrm{a})$ \\
\hline desert feral & 11 & $64.91 \pm 23.95(\mathrm{c})$ & $472.35 \pm 141.79(b)$ \\
\hline úšik \#2 & 6 & $47.19 \pm 12.03(d)$ & $378.77 \pm 95.67(\mathrm{c})$ \\
\hline ayzāl & 2 & $87.26 \pm 22.72$ (a) & $363.30 \pm 71.29(\mathrm{c})$ \\
\hline úšik niqbel & 3 & $29.08 \pm 6.315(\mathrm{e})$ & $280.83 \pm 47.66(\mathrm{~d})$ \\
\hline úšik ezzuway & 4 & $70.80 \pm 25.08(b)$ & $276.59 \pm 52.15(\mathrm{~d})$ \\
\hline$k a \varepsilon i b \bar{\imath}$ & 1 & $14.78 \pm 3.47(\mathrm{gh})$ & $272.90 \pm 43.46(d)$ \\
\hline șąidi & 11 & $28.88 \pm 12.74(\mathrm{e})$ & $262.76 \pm 53.15(\mathrm{~d})$ \\
\hline tatțagt & 2 & $20.50 \pm 6.70(f)$ & $261.64 \pm 48.29(\mathrm{~d})$ \\
\hline alkak & 4 & $20.94 \pm 6.62(f)$ & $231.49 \pm 43.58(\mathrm{e})$ \\
\hline from ayzāl & 2 & $68.43 \pm 16.37(\mathrm{bc})$ & $219.23 \pm 44.30(\mathrm{e})$ \\
\hline alkak wen žemb & 1 & $10.07 \pm 2.16$ (hi) & $173.95 \pm 17.90(f)$ \\
\hline úšik nekwayes & 1 & $19.59 \pm 7.79(\mathrm{fg})$ & $167.77 \pm 23.74(f)$ \\
\hline úšik amayzuz & 1 & $8.95 \pm 1.71$ (i) & $100.49 \pm 10.69(\mathrm{~g})$ \\
\hline
\end{tabular}

garden and palm grove seedlings were assigned positively. In this case, it is interesting to note the inconsistency of the úšik group: all seedlings do not form a consistent group and growing within a garden makes a difference.

Similarly, we found that the 11 samples of saridi and the four samples of alkak are easily assigned (respectively 80.4 and $79.7 \%$ ), in accordance with the fact that the intra-varietal variability is low within sasidi and alkak samples and despite the fact that those samples were collected in very different gardens, so subject to different cultivation conditions (Table 4). Úšik \#1 and \#2 have a low cross-validation (CV) percentage since they are not clones. Surprisingly, feral samples have a high CV percentage even though they are also not clones. This may be related to the fact over generations these palms, neither tended nor artificially selected, produce seeds that converge towards an "ideal" shape and size relative to their environment through natural selection (Siegal and Bergman 2002; Gros-Balthazard et al. 2016).

\section{Ethnobotanical Study ${ }^{6}$}

The term $u ́ s ̌ i k$, when part of a cultivar name, emphasizes the origin of the genetic lineage as the outcome of a farmer sparing a random female seedling and then reproducing and naming it. Only named date palms in Siwa are propagated vegetatively. A larger genetic stock, however, exists, mainly as úšik seedlings within gardens (úšik\#1) and in communal spaces of the palm grove and its margins (úšik \#2), or in the abandoned palm groves (for centuries, possibly since the late Roman period) scattered in the Libyan desert around Siwa (agzzo pl.

\footnotetext{
${ }^{6}$ See Battesti (2013) and the Introduction above for a full account; also Fig. S1.
} 

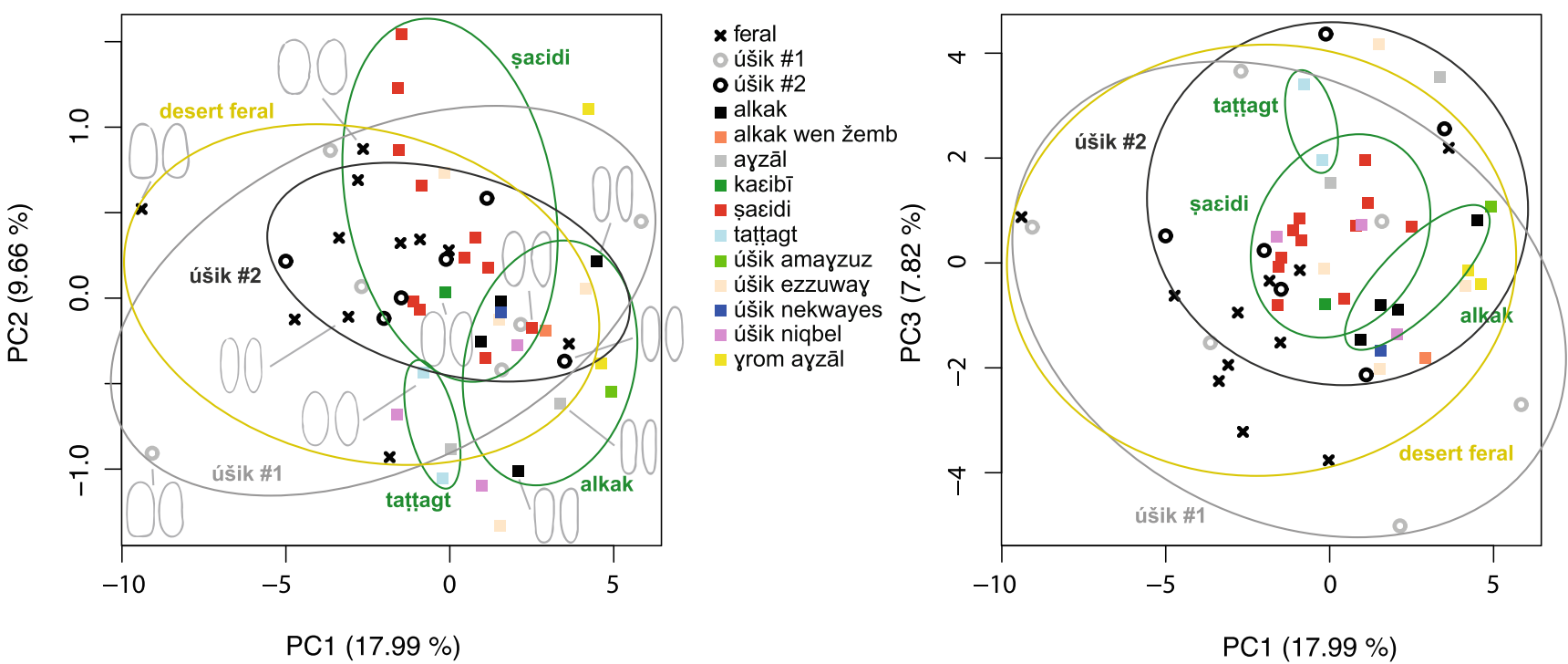

Fig. 5 Principal Component Analysis (PCA) on 55 date palm accessions based on seed size and shape

igizzã in all likelihood also descendants of a cultivated population). The term "ethnovariety" (Battesti 2013) referring to the local way of organizing the biodiversity of date palms in Siwa, including new genetic lines in the cultivated pool, relates the two compartments "cultivated palms" and "feral palms and seedlings," which are usually thought to be impermeable to each other.

In regard to ethnovarieties Pérau-Leroy, an agronomist working in Morocco under the last days of the French protectorate, 60 years ago, wrote: "the variety should be a single clone and therefore come from a single parent plant. But as it can appear among the seedlings a subject resembling very much a variety, it has happened that this subject was at the origin of a new clone, which was assimilated to the variety already known and spread under its name" (1958: 99-100, translation by the authors). It is difficult to guess whether what is acknowledged here is the result of an error or a conscious cultural practice as in Siwa. Pérau-Leroy also identifies "another origin of these lines [that] can be found in somatic mutations that involve only little-evident physiological or morphological characteristics. Thus, come to be gathered together under the same name, slightly different clones" (ibid.), and points out: "It is clear that the recognition of these lines is of particular practical interest, especially for the selection of varieties resistant to fusarium wilt, because when a variety includes several clones, one clone may have a different reaction to the disease than the others, and the observer may misjudge the behavior of the whole variety with respect to the disease" (ibid.).

Assuming that the creation of an ethnovariety is the result of a horticultural technique, we still have to distinguish between two possibilities: a) the accidental occurrence of seedlings and their voluntary incorporation into the collection of known varieties (due to their similarity), and b) the deliberate search for identical seedlings to cultivate using the backcross technique (Battesti 2013: §62). Kearney (1906) describes another technique used in Jerid (Tunisia): "Seedling palms are, of course, rarely true to type, although the writer was gravely assured by an intelligent Arab that to make them come true it is only necessary to transplant them two or three times, and that this method is sometimes resorted to when suckers are not procurable, in order to perpetuate very rare varieties!" (43).

\section{Discussion}

In order to understand the intraspecific agrobiodiversity of a cultivated plant, it is important to understand the local perspective of those who farm it (Figs. 6 and 7). Battesti (2013) highlighted two facts: the first, quantitative, is that about 15 or so named types (cultivars and ethnovarieties) exist in Siwa oasis; the second, qualitative, is that shape matters, but genes probably matter little. In other words, for farmers, the morphologic resemblance produces identity, and this has implications for the richness of this resource. The purpose of the present study was to validate those statements and clarify the local categorization of this unique plant and its cultivars using genetic markers. To this end, we combined a scientific study based on genetic identity and ethnographic data from Siwa oasis farmers based on phenotypic identity.

\section{Are Cultivars of Siwa Oasis Vegetatively Propagated (True-to-Type Clones)?}

The genetic analysis confirms the local Isiwan statement that the named types șazidi and tattagt are true cultivars. The very slight genetic difference among șąidi accessions is 
Fig. 6 A farmer harvesting the dates of his garden in Abregani palm grove, Siwa oasis (Egypt), Nov. 15th, 2014. Vincent Battesti

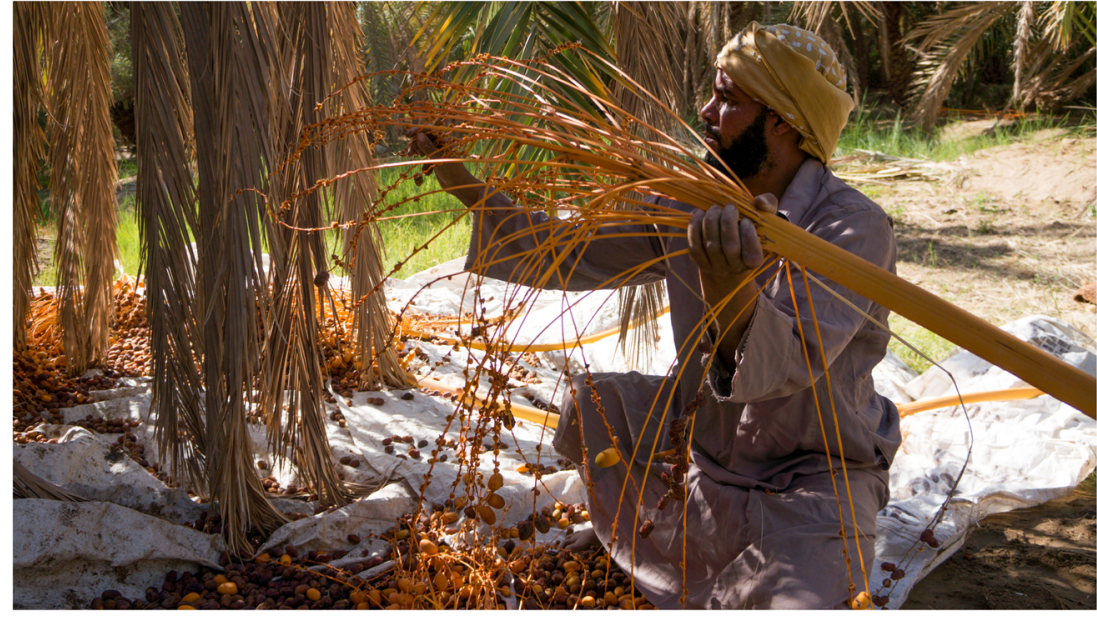

presumably the result of somatic mutations. Additionally, the morphometric analysis clearly identifies all the șacidi samples as having similar seed shape (Table 4). Although these accessions were collected in distant gardens in all Siwa palm groves, they apparently all originate from the vegetative reproduction of a single ancestor (Fig. 7). We were even able to correct a sample mislabeled as úšik to șasidi. The genetic analysis should also have confirmed the local Isiwan statement that the named type alkak, for instance, is a true cultivar, but although very closely related, our two alkak accessions are not perfect true-to-type clones. Whether this is the result of somatic mutations or of the fact that it is not a true cultivar is difficult to determine with our current data.

Based on genetic data (Table 5, Fig. 2), the given names úšik ezzuway and úšik niqbel appear as ethnovarieties rather than true cultivars. The ethnographic data predicted this for úšik ezzuway, which has a "controversial status" among farmers of Siwa oasis regarding the existence of a single clone (Fig. S1). The case of úšik niqbel is more puzzling as this was supposed to be the name of a true-to-type cultivar and not of an ethnovariety (Fig. S1). Interestingly, the dates from úšik ezzuway accessions are morphologically very similar (round and reddish/black, "ezzuway" is related to the red color in Amazigh) just as all the dates from úšik niqbel accessions are apparently similar (fleshy, oblong and brown dates), as are from ayzāl dates (yellow unripe and brown ripe). The local primacy of the phenotype over the genotype is definitively corroborated by the position of the úsik ezzuway (2412) and the from ayzāl (2065) in the NJ tree. Even if they are genetically closely related, they do not share a common name as they display different forms. The ethnographic data strongly suggest that úšik nekwayes and kaعibi are more likely ethnovarieties rather than true cultivars (Fig. S1) but we do not have the scientific data necessary to verify this.

Based on our results, we argue that, against all expectations, named types in Siwa could correspond to ethnovarieties as a general rule, with cultivars being the exceptions. The ethnographic analysis combined with genetic analysis indeed confirm that the "genetic identity"-which is the classic and scientific definition of a true-to-type cultivar for the date palm-does not matter per se for local farmers; but "shape
Fig. 7 During the date harvest in a garden of Azzumuri palm grove in Siwa oasis (Egypt), a farmer picks up șąidi dates, Dec. 5th, 2013. Vincent Battesti

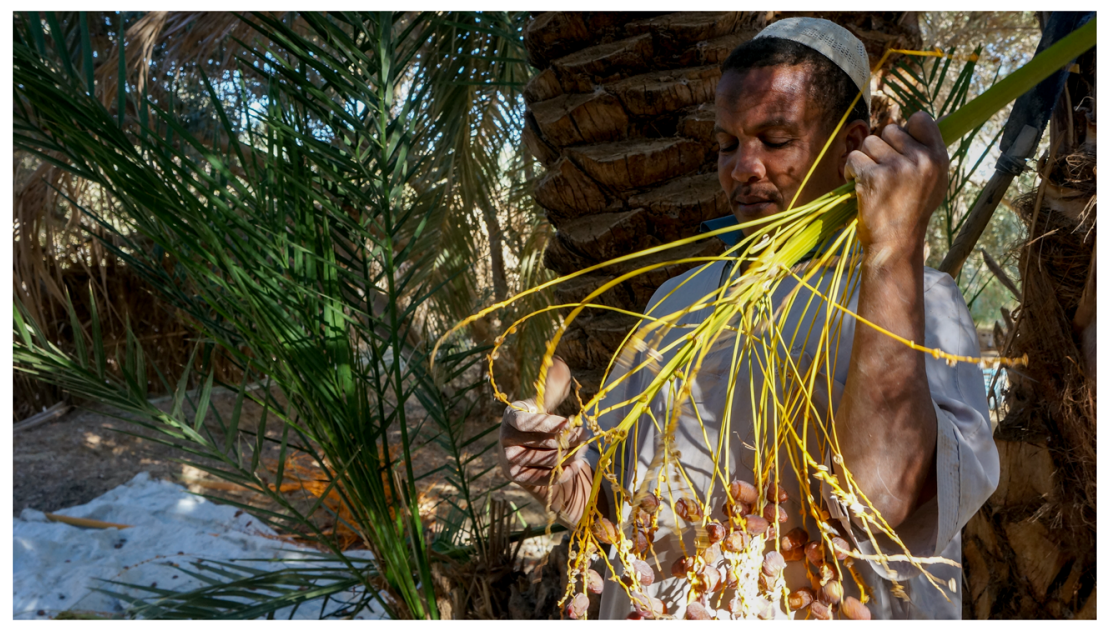


Table 4 Percent of cross validation $(\mathrm{CV})$ for each variety/category

\begin{tabular}{lll}
\hline Type & \# Accessions & CV \\
\hline úšik amayzuz & 1 & 86.17 \\
șacidi & 11 & 80.38 \\
alkak & 4 & 79.72 \\
desert feral & 11 & 79.04 \\
úšik nekwayes & 1 & 76.93 \\
alkak wen žemb & 1 & 73.38 \\
tațtagt & 2 & 73.11 \\
yrom ayzāl & 2 & 69.43 \\
ayzāl & 2 & 67.31 \\
kacibī & 1 & 53.44 \\
úšik \#2 & 6 & 51.95 \\
úšik \#1 & 6 & 49.88 \\
úšik ezzuway & 4 & 48.19 \\
úšik niqbel & 3 & 43.37 \\
\hline
\end{tabular}

identity" does. That means that a seedling date palm sharing a shape similarity (plant or fruit) with a known cultivar can be "added" to this cultivar permanently: it will also eventually be vegetatively reproduced by farmers and the given name will no longer refer to a cultivar (a single line of clones) but to an ethnovariety (multiple lines of clones).

\section{Feral and Seedlings Versus Cultivated Palms}

Two facts emerge from this study regarding feral status in contrast with cultivated samples. Firstly, desert feral date palms could be the remains of a putative ancient gene pool from which were drawn a cultivar like tattagt, but also some current úšik date palms (growing in a garden or untended in the palm grove). Secondly, úsik date palms are a true gene pool for the farmers (in the past and the present), offering a wide genetic and

Table 5 Average percentage of similarity calculated with genetic data within each named type of Siwa

\begin{tabular}{lll}
\hline Variety & \# Accessions & Percentage \\
\hline alkak & 2 & 91.18 \\
alkak wen žemb & 1 & $/$ \\
ayzāl & 2 & 60.61 \\
desert feral & 12 & 17.65 \\
șacidi & 5 & 96.97 \\
tațagt & 2 & 96.77 \\
úšik \#1 & 8 & 18.18 \\
úšik \#2 & 8 & 26.47 \\
úšik amayzuz & 1 & $/$ \\
úšik ezzuway & 2 & 41.18 \\
úšik nekwayes & 1 & $/$ \\
úšik niqbel & 2 & 65.63 \\
yrom ayzāl & 1 & $/$ \\
\hline
\end{tabular}

morphological diversity. They constitute a possible original pool from which stems part of the current diversity of cultivars, as well as a pool continuously being regenerated by sexual reproduction between cultivated and uncultivated individuals. In this respect, úšik date palms should deserve a closer attention in scientific analyses of agrobiodiversity. Some studies have already drawn our attention to this topic, for example, Peyron et al. (1990: 122) states that seedlings "represent an exceptional genetic stock" or more recently Johnson et al. (2013: 826) who conclude that "as the original source of all cultivar dates, seedling dates continue to be present, to varying degrees, in all dategrowing areas (...) and represent unevaluated germplasm resources."

\section{Focusing on the Date Palms, the Dates, and their Shape}

For local farmers, the form of the date palm, its soil and climatic requirements, and the form and quality of its fruit are the understandable keys to categorizing their date palms. Maintaining palm groves is primarily to produce dates, with a diversity that meets export and local demands (different tastes, different preservation capacities, different uses, and different harvest seasons). Locally, the form and quality of fruits prevail over the genetic proximity, except that local farmers know that the best way to obtain another date palm bearing the required form and quality of fruit is to use vegetative reproduction, but not the only one. Our genetic and morphometric analyses are congruent but fail together sometimes to duplicate the local categorization of date palm biodiversity because of the existence of local ethnovarieties in Siwa. Preliminary observations on the naming of date types in other producing areas (in Egypt and Oman) indicate that similar patterns emerge that would require similar treatment to compare to this first case study.

McKey et al. (2010) consider that a key component of strategies for preserving the adaptive potential of clonal crops is the maintenance of mixed clonal/sexual systems, which can be achieved by encouraging and valuing farmer knowledge about the sexual reproductive biology of their clonal crops. This may have interesting consequences for the processes of domestication: using ethnovarieties as a tool to categorize cultivated date palms and maintaining a population of feral (or seedling) date palms in Siwa palm groves as a genetic improvement pool could be seen as an ingenious mixed clonal/ sexual system strategy (Fig. 8).

\section{General Pattern of Diversity in Siwa Oasis}

The genetic proximity of all the feral accessions from ancient and abandoned oases in the same clade in the distance tree may suggest an old gene pool of cultivated date palms that survives in current cultivated date palms of Siwa through 
Fig. 8 Untended seedling date palms, on the edge of the Bared al-Dīn palm grove, West part of Siwa oasis (Egypt), May 21st, 2013, Vincent Battesti

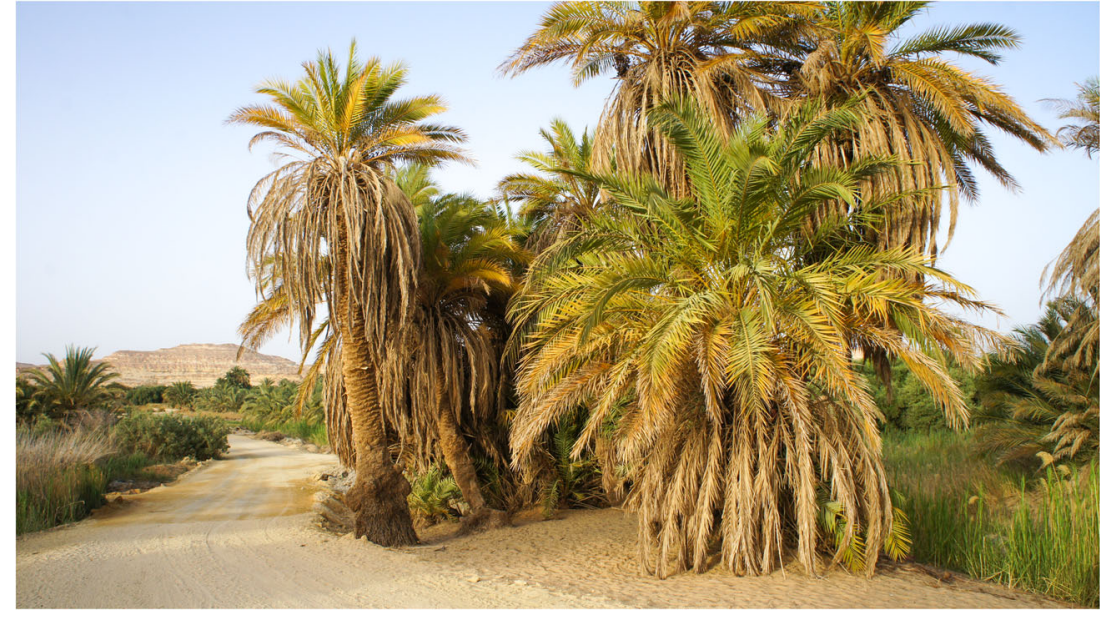

tațtagt, yrom ayzāl, some úšik ezzuway and some garden and palm grove seedling date palms (úšik\#1 and úšik\#2) (Fig. 2). This hypothesis leads to possibility that the other forms of date palm may have been introduced to Siwa, perhaps including șacidi and alkak.

Our ethnographic study showed that even if the richness of the date palm heritage of Siwa is celebrated, and despite the apparent abundance of variety names in the literature, we have only about 15 different given names (Battesti 2013), and that an unknown portion of these are not of "true" cultivars but "ethnovarieties." Therefore, beyond the apparent agrobiodiversity a "hidden genetic richness" exists (more than one clone per given name), all those clones duly selected and reproduced by the local farmers. Nonetheless, this number stays small in comparison with other oasis regions such as the Jerid in Tunisia where 220 varieties are cultivated (Rhouma 1994, 2005; Battesti 2015).

\section{Diversity Structure Explained by Economic Strategy}

There may be a historical explanation for this low number of given names: when Siwa oasis was re-founded during the eleventh or twelfth century (Battesti 2013: §89), the settlers probably had a clear plan for an economy based on the exportation of two complementary elite date cultivars: șacidi for urban populations (especially Cairo and Alexandria) and alkak for the those people transporting the sacidi over long distances - especially the Bedouin of the Awlad 'Ali tribe. It is possible, although there is no evidence, that the Bedouin kept reserves of alkak dry dates in underground silos. According to Cole and Altorki (1998: 139), "the grain from the barley was, and is, stored in pits about two meters deep known as matmura" by the Awlad "Ali. The technique was used in Fezzan in sand pits for dry dates, where "the hard, dry dates are said to keep satisfactorily for two or three years" (Dowson and Aten 1962: 120). Wansleb noted as early as 1664 the arrivals in Alexandria of camel caravans loaded with the famous șa cidi dates of Siwa, packed in woven baskets (Wansleb 1794 [1664]: 46, translation by the authors).

There was mention of the export of two elite varieties of date, șacidi and alkak, from Siwa at least two centuries ago (for a detailed review, see Battesti 2013), in addition to the high value ayzāl, which was produced and exported only in small quantities. Its Arabic trade name was sulțāni, "the
Fig. 9 A garden in the Siwa palm grove (Egypt), with date palms that have been poorly cleaned and encroached upon by various species of spontaneous herbaceous plants, a sign of low labour investment. Nov. 9th, 2014, Vincent Battesti

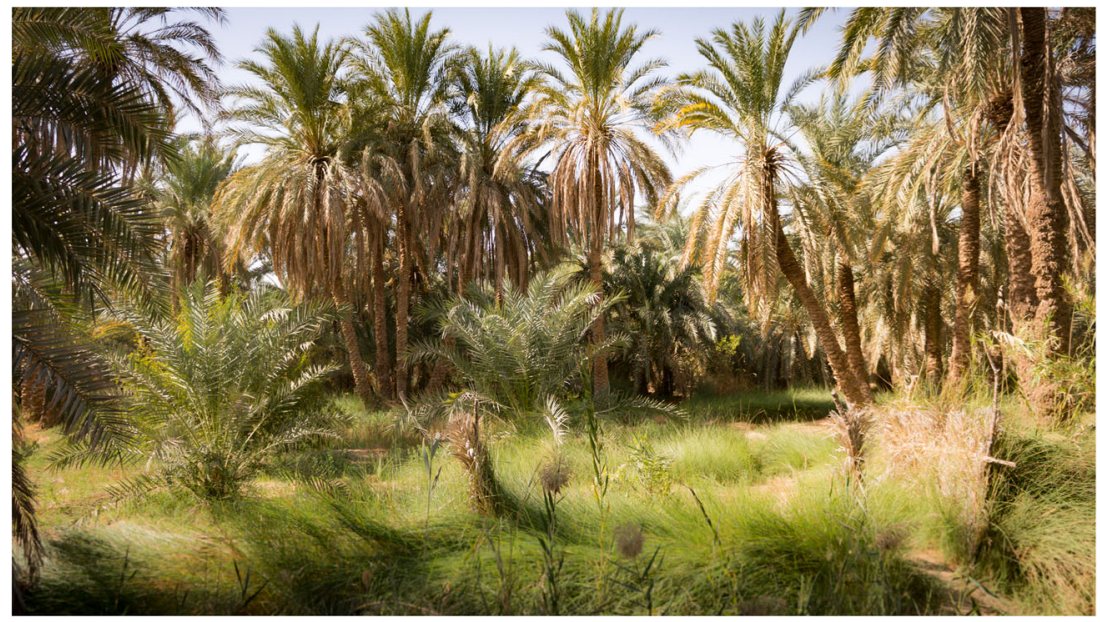


Fig. 10 Synthetic presentation of the relationships between phenotype and morphotype with local vs. science categorization regarding date palms

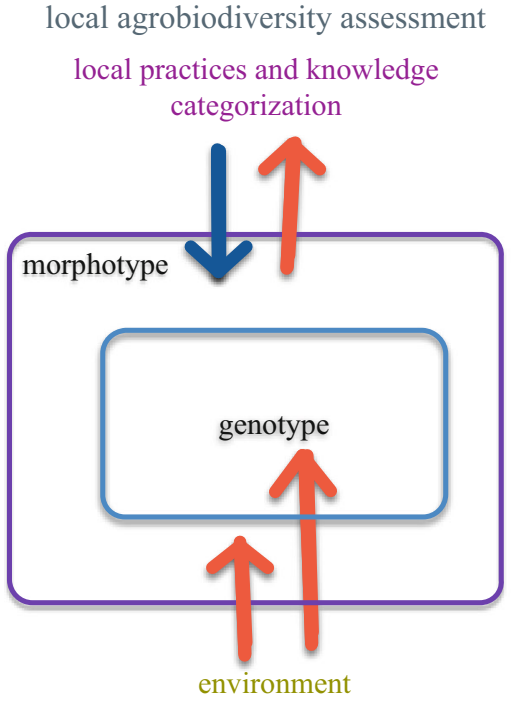

genetic biodiversity assessment science practices and knowledge categorization

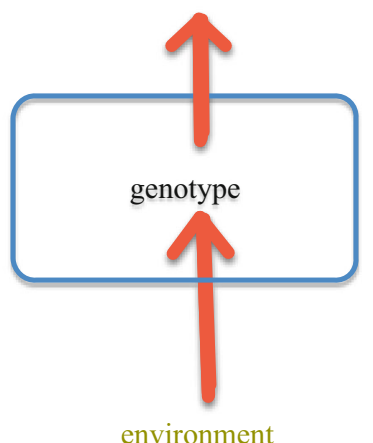

environment sultana" (but the name is sometimes used for other varieties), and it is valued by the Isiwan as a tonic for lack of energy (Fakhry 1990: 27) and for its aphrodisiac properties (for men). Drovetti and Cailliaud described these dates as "the most delicate and far superior to all those eaten in Egypt" (Jomard 1823: 9, translation by the authors), and they add that the Isiwan "forbid women to eat sultana dates: this fruit, they say, would make them too voluptuous, too prone to love" (ibid.: 12, see also: Minutoli 1827: 91).

The large-scale cultivation of two favored varieties appears to be longstanding in Siwa and suggests a strong integration of date palm farming with an export economy. According to Steindorff's estimates of the value of agricultural products in the oasis (Steindorff 1904: 113, translation by the authors), 95\% of șazidi and $97 \%$ of frehi [alkak] are exported, but only $33 \%$ of úsik (low value and consumed locally by humans and livestock). In total, the oasis exports, in value, $82 \%$ of its date harvest via trans-Saharan networks that seem to have been well established since Antiquity (Wilson 2012; Kuhlmann 2013; Battesti in press).
Local memory and the literature (e.g., Rusch and Stein 1988) testify to the close link between the sedentary Siwi population and the Bedouin population, especially the Awlad 'Ali, who are today largely settled in and around Marsa Matruh on the Mediterranean coast. Scholz (1822: 32) reported the Isiwan deal with "the horde of Valedali" [Awlad 'Ali] and that "they carry on their trade by barter, exchanging their dates, olives, cattle, and handsome baskets made of palm leaves, for corn, tobacco, manufactured goods, especially linen, coffee, \&c., which are brought by the Arabs from Alexandria, or by the Bedouin." The Aoulâd-Aly are reported to "exchange dates in Syouah and Audjelah for butter and cattle ... their usual diet consists of dry dates, milk, and barley and wheat flour" (Pacho 1827: 74, translation by the authors). Later, von Fircks (1895: 75 , translation by the authors) wrote that "The export of dates and the import of Egyptian grain for the inhabitants of the oasis is mediated by the powerful tribe of Aülad Ali Bedouin," and Robecchi-Bricchetti (1890:

Fig. 11 On the borders of the Maraqi palm grove, East part of Siwa oasis (Egypt), Nov. 6th, 2015, Vincent Battesti

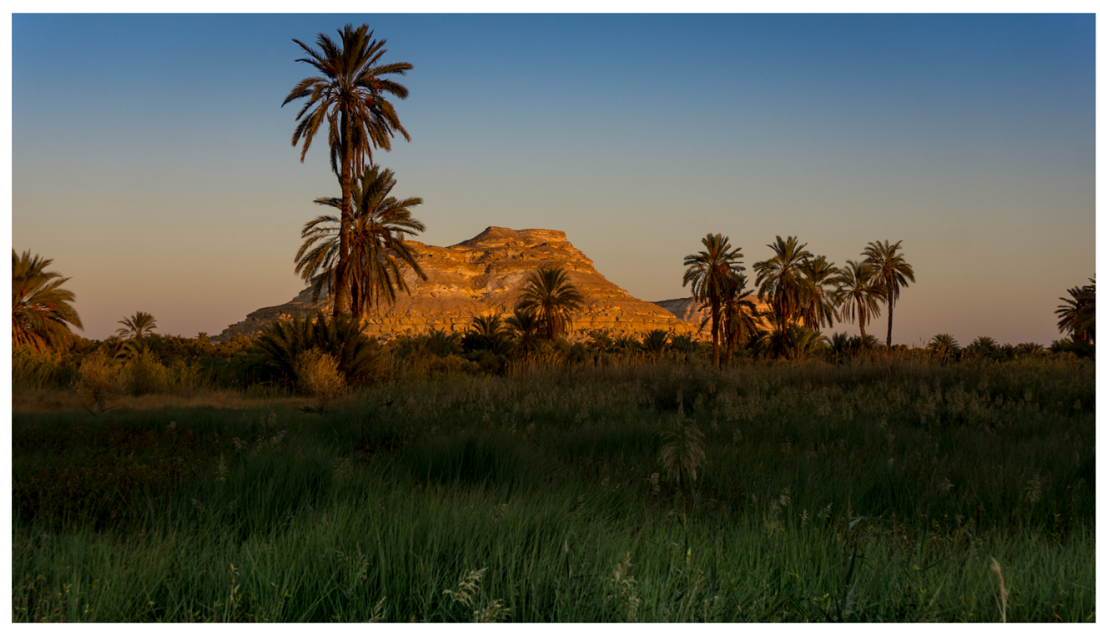


242 , translation by the authors) reports "in the past, one of the largest caravans was that of the Ualad-Ali, which transported more than 30,000 quintals of dates to Egypt alone, from October to March. Presently, the export trade is carried out by Bedouin Ualad-Ali, Ualad elDorri, Senagrah, Fezzanesi and Barberini, who export more than 50,000 quintals of dates annually." White (1899: 156-157) writes "the western traffic is in the hands of those enterprising merchants and slave-traders, the Mojabra. The eastern traffic is practically the monopoly of the Waled Ali-now more or less tractable subjects of Egypt-, who follow the Coastal route, through their own territory, to Alexandria. The Cairene traffic is shared by the Arabs of Kadassi, a village near the Pyramids." According to Falls (1913: 277), "the exportation [of dates] takes place in the winter months, and is entirely in the hands of the Auladali [Awlad 'Ali] Bedouin, whose caravans then number as many as one hundred camels," whereas Murray (1935: 22) describes it as in the hands of both the "Awlad "Ali" and "Harabi" (closely related, according to Evans-Pritchard 1949: 49). Cline (1936: 11) provides a description of the Siwa market where the Isiwan merchants engage in this trade with the Bedouins and Arabs. Finally, the anthropologists Cole and Altorki (1998) describe the sadaqa (friendship, sometimes hereditary) that unites Bedouin families with particular Siwi merchants.

\section{Conclusion}

We used a combined approach of social and biological sciences to establish the existence of ethnovarieties in the date palm agrobiodiversity of Siwa: some date palms appear the same (according to local criteria) and have the same name despite substantial genetic differences. Consequently, a hidden genetic richness exists beyond the apparent agrobiodiversity. The seedling date palms seem to be a true gene pool for the date palm farmers and are possibly part of the original pool for the current diversity of cultivars (Fig. 9).

Local farmers of Siwa oasis are attuned to phenotypic traits in their categorization as they have access to the phenotype of their date palms, which this influences the local management of germplasm, and subsequently determines genetic diversity and distribution. Local farmers fully acknowledge that phenotype is shaped by inheritance from both male and female plants (the female has more influence on the fruit) and by soil and climatic conditions. This situation challenges the conventional assessment of diversity based on genetic identity alone (Fig. 10).
Agrobiodiversity is the result of management by generations of farmers: we cannot ignore their knowledge and practices. Future studies should analyze an expanded collection of genetic samples of date palms from Siwa in order to better assess the status of local varieties as cultivars or ethnovarieties and to help us better understand the biogeography of Siwa date palms in relation to supra-regional date palm diversity (Fig. 11).

Funding This study was funded by GDR 3353 Mosaïque (2013 INEE, CNRS France), supported by the Agence nationale de la recherche (France): programme blanc, ANR-06- BLAN-0212-02-PHOENIX project (dir. M. Tengberg; WP coordinated by J.-F. Terral), and by $\mathrm{PhD}$ fellowships from the French Ministry of Research granted to Muriel Gros-Balthazard. The funders had no role in study design, data collection, and analysis, decision to publish, or preparation of the manuscript. This article is the ISEM 2018-018 contribution.

\section{Compliance with Ethical Standards}

Conflict of Interest The authors declare that they have no conflict of interest.

\section{References}

Abd El-Azeem, R. M., Hashem, M. H., and Hemeida, A. A. (2011). Identification and genetic similarity analysis of date palm (Phoenix dactylifera L.) collected from different regions in Siwa Oasis using morphologically traits and molecular markers. Egyptian Journal of Genetics and Cytology 40(2): 281-300 http://www.esg.net.eg/pdf/ 281-300 july2011.pdf.

Aberlenc-Bertossi F., Castillo K., Tranchant-Dubreuil C., Chérif E., Ballardini M., Abdoulkader S., Gros-Balthazard M., Chabrillange N., Santoni S., Mercuri A., and Pintaud J.-C. (2014). In Silico Mining of Microsatellites in Coding Sequences of the Date Palm (Arecaceae) Genome, Characterization, and Transferability. Applications in Plant Sciences 2(1): 1-5. https://doi.org/10.3732/ apps. 1300058

Abou Gabal, A. A., Abedel Aziz, A. A., Harhash, M. M., and El-Wakil, H. F. (2006). Genetic diversity among seven date palm landraces in Siwa Oasis. Egyptian Journal of Genetics and Cytology 35: 117-128.

Abràmoff, M. D., Magalhães, P. J., and Ram, S. J. (2004). Image processing with image J. Biophotonics international 11(7): 36-42 http:// dspace.library.uu.nl/handle/1874/204900.

Adawy, S. S., Hussein, E. H. A., Ismail, S. E. M. E., and El-Itriby, H. A. (2005). Genomic diversity in date palm (Phoenix dactylifera L.) as revealed by AFLPs in comparison to RAPDs and ISSRs. Arab. Journal of Biotechnology 8(1): 99-114 http://www.acgssr.org/ BioTechnology/V8N1January2005.asp.

Ahmed, T. A., Al-Hadidi, S. H., Al-Qaradawi, A. Y., and Radwan, O. (2013). Determination of inter- and intra-specific genetic variations among Qatari date palm cultivars using inter simple sequence repeat (ISSR) markers. African Journal of Biotechnology 12(19): 2540-

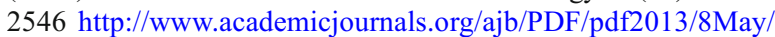
Ahmed\%20et\%20al.pdf.

Barrow, S. (1998). A monograph of Phoenix L. (Palmae: Coryphoideae). Kew Bull. 53: 513-575.

Battesti V. (2005). Jardins au désert, Évolution des pratiques et savoirs oasiens. Jérid tunisien. Éditions IRD, À travers champs, Paris. 440 p. http:/hal.archives-ouvertes.fr/halshs-00004609 
Battesti V. (2006). "Pourquoi j'irais voir d'en haut ce que je connais déjà d'en bas ?" Comprendre l'usage des espaces dans l'oasis de Siwa. In Battesti V., and Puig N. (eds.), Terrains d'Égypte, anthropologies contemporaines, CEDEJ, Le Caire. https://doi.org/10.4000/ema. 1967

Battesti V. (2012). The power of a disappearance: Water in the Jerid region of Tunisia. In Johnston B. R., Hiwasaki L., Klaver I. J. et al. (eds.), Water, cultural diversity, and global environmental change: Emerging Trends, Sustainable Futures?, Unesco/Springer, Paris, Jakarta. https://doi.org/10.1007/978-94-007-1774-9_6

Battesti V. (2013). L'agrobiodiversité du dattier (Phoenix dactylifera L.) dans l'oasis de Siwa (Égypte) : entre ce qui se dit, s'écrit et s'oublie. Revue d'ethnoécologie 4 (The Date Palm: Origin and Cultivation in the Middle East and in Egypt). https://doi.org/10.4000/ ethnoecologie. 1538

Battesti V. (2015). Resources and Appropriations: Back to the Jerid Oases (Tunisia) after the Revolution. Études rurales 2013/2(192): 153175. https://www.cairn.info/revue-etudes-rurales-2013-2-page153.htm

Battesti V. (2018). Les possibilités d'une île, Insularités oasiennes au Sahara et genèse des oasis. In Sauzeau T., and Tallet G. (eds.), Mer et désert de l'Antiquité à nos jours, Approches croisées, Presses universitaires de Rennes, Rennes. https://hal.archivesouvertes.fr/hal-01154828

Billotte N., Marseillac N., Brottier P., Noyer J.-L., Jacquemoud-Collet J.P., Moreau C., Couvreur T., Chevallier M.-H., Pintaud J.-C., and Risterucci A.-M. (2004). Nuclear microsatellite markers for the date palm (Phoenix dactylifera L.) : characterization and utility across the genus Phoenix and in other palm genera. Molecular Ecology Notes 4(2): $256-258$

Bodian A., El Houmaizi M. A., Ndoye Ndir K., Hasnaoui A., Nachtigall M., and Wehling P. (2012). Genetic diversity analysis of date palm (Phoenix dactylifera L.) cultivars from Figuig oasis (Morocco) using SSR markers. International Journal of Science and Advanced Technology 2(3): 96-104. http://www.ijsat.com/pdf. php?pdf id=378.pdf

Bodian A., Nachtigall M., Frese L., Elhoumaizi M. A., Hasnaoui A., Ndoye Ndir K., and Sané D. (2014). Genetic Diversity Analysis of Date Palm (Phoenix dactylifera L.) Cultivars from Morocco Using SSR Markers. Journal of Biodiversity, Bioprospecting and Development 1(3, Genetic Diversity and Molecular Evolution): 126. https://doi.org/10.4172/2376-0214.1000126

Bonhomme, V., Picq, S., Gaucherel, C., and Claude, J. (2014). Momocs: Outline analysis using R. Journal of Statistical Software 1(13). https://doi.org/10.18637/jss.v056.i13.

Capmas (2016). Population Census kism/markaz 2016 Egypt/Matrouh/ Siwa Markaz. website, Arab Republic of Egypt, Central Agency for Public Mobilization And Statistics, online: http://www.capmas.gov. eg/Pages/StaticPages.aspx?page id=7188, access: Dec. 2017.

Capmas (2018). Census-population of Egypt, statistic databases. Website, Arab Republic of Egypt, central Agency for Public Mobilization and Statistics, online: http://www.capmas.gov.eg

Cline W. B. (1936). Notes on the people of Siwah and El Garah in the Libyan desert. George Banta Publishing Company, General series in anthropology, $\mathrm{n}^{\circ}$ 4, Menasha, Wis. $64 \mathrm{p}$.

Cole D. P., and Altorki S. (1998). Bedouin, Settlers, and Holiday-Makers, Egypt's Changing Northwest Coast. American University in Cairo Press, Cairo. xvi; 246 p.

Devanand, P. S., and Chao, C.-C. T. (2003). Genetic variation in 'Medjool' and 'Deglet Noor' date (Phoenix dactylifera L.) cultivars in California detected by fluorescent-AFLP markers. Journal of Horticultural Science and Biotechnology 78(3): 405-409.

Dowson, V. H. W., and Aten, A. (1962). Dates, handling, processing and packing. FAO, FAO Agric. Development paper, $n^{\circ} 72$. Rome. xxiv: 392. https://archive.org/details/bub_gb_gZah4jmWlGUC.
Dray, S., and Dufour, A.-B. (2007). The ade4 package: Implementing the duality diagram for ecologists. Journal of Statistical Software 22(4). https://www.jstatsoft.org/article/view/v022i04.

Duputié A., Massol F., David P., Haxaire C., and McKey D. (2009). Traditional Amerindian cultivators combine directional and ideotypic selection for sustainable management of cassava genetic diversity. Journal of Evolutionary Biology 22(6): 1317-1325. https:// doi.org/10.1111/j.1420-9101.2009.01749.x

El-Assar, A. M., Krueger, R. R., Devanand, P. S., and Chao, C.-C. T (2005). Genetic analysis of Egyptian date (Phoenix dactylifera L.) accessions using AFLP markers. Genetic Resources and Crop Evolution 52: 601-607.

Elhoumaizi, M. A., Devanand, P. S., Fang, J., and Chao, C.-C. T. (2006). Confirmation of 'Medjool' date as a landrace variety through genetic analysis of 'Medjool' accessions in Morocco. Journal of the American Society for Horticultural Science 131(3): 403-407.

Evans-Pritchard E. E. (1949). The Sanusi of Cyrenaica. Clarendon Press, Oxford. 248 p. https://archive.org/details/TheSanusiOfCyrenaica

Fakhry A. (1990). Siwa Oasis. American University in Cairo Press, Cairo, Egypt. $x, 214$ p.

Falls J. C. E. (1913). Three years in the Libyan desert, travels, discoveries and excavations of the Menas expedition (Kaufmann Expedition). Leipsic, T.F. Unwin, London. 356 p. http://catalog.hathitrust.org/ Record/010109757

von Fircks A. R. G. H. T. (1895). Aegypten 1894, Staatsrechtliche Verhältnisse, wirthschaft licher Zustand, Verwaltung, Nach amtlichen und anderen Quellen sowie eigenen Wahrnehmungen dargestellt. Verlag von Dietrich Reimer, Berlin. VIII, 300 p.

Gepts P., Famula T. R., Bettinger R. L., Brush S. B., Damania A. B., McGuire P. E., and Qualset C. (eds.) (2012). Biodiversity in Agriculture : Domestication, Evolution, and Sustainability, Cambridge University Press, Cambridge ; New York.

Gros-Balthazard M., Newton C., Ivorra S., Pierre M.-H., Pintaud J.-C., and Terral J.-F. (2016). The Domestication Syndrome in Phoenix dactylifera Seeds: Toward the Identification of Wild Date Palm Populations. PLoS ONE 11(3): e0152394. https://doi.org/10.1371/ journal.pone.0152394

Gros-Balthazard, M., Galimberti, M., Kousathanas, A., Newton, C., Ivorra, C., Paradis, L., Vigouroux, Y., Carter, R., Tengberg, M., Battesti, V., Santoni, S., Falquet, L., Pintaud, J.-C., Terral, J.-F., and Wegmann, D. (2017). The discovery of wild date palms in Oman reveals a complex domestication history involving centers in the Middle East and Africa. Current Biology. https://doi.org/10. 1016/j.cub.2017.06.045.

Gurevich, V., Lavi, U., and Cohen, Y. (2005). Genetic variation in date palms propagated from offshoots and tissue culture. Journal of the American Society for Horticultural Science 130(1): 46-53 http:// journal.ashspublications.org/content/130/1/46.

Hazzouri K. M., Flowers J. M., Visser H. J., Khierallah H. S. M., Rosas U., Pham G. M., Meyer R. S., Johansen C. K., Fresquez Z. A., Masmoudi K., Haider N., El Kadri N., Idaghdour Y., Malek J. A., Thirkhill D., Markhand G. S., Krueger R. R., Zaid A., and Purugganan M. D. (2015). Whole genome re-sequencing of date palms yields insights into diversification of a fruit tree crop. Nature Communications 6: 8824. https://doi.org/10.1038/ ncomms 9824

Hussein, E. H. A., Adawy, S. S., Ismail, S. E. M. E., and El-Itriby, H. A. (2005). Molecular characterization of some Egyptian date palm germplasm using RAPD and ISSR markers. Arab Journal of Biotechnology 8(1): 83-98 http://www.acgssr.org/BioTechnology/ V8N1January2005.asp.

Jain, S. M. (2012). Date palm biotechnology: Current status and prospective - an overview. Emirates Journal of Food and Agriculture 24(5): 400-407 http://www.ejfa.me/index.php/journal/article/view/923 
Johnson, D. V., Al-Khayri, J. M., and Jain, S. M. (2013). Seedling date palms (Phoenix dactylifera L.) as genetic resources. Emirates Journal of Food \& Agriculture (EJFA) 25(11): 809-830.

Jomard E. F. (1823). Voyage à l'oasis de Syouah, rédigé et publié par M. Jomard,... d'après les matériaux recueillis par M. le chevalier Drovetti,... et par M. Frédéric Cailliaud, pendant leurs voyages dans cette oasis en 1819 et en 1820. Imprimerie de Rignoux, Paris. 20 pl., $28 \mathrm{p}$.

Kamvar, Z. N., Tabima, J. F., and Grünwald, N. J. (2014). Poppr: An R package for genetic analysis of populations with clonal, partially clonal, and/or sexual reproduction. PeerJ 2: e281. https://doi.org/ 10.7717/peerj.281.

Kearney T. H. (1906). Date varieties and date culture in Tunis. Government Printing Office, U.S. Department of Agriculture. Bureau of Plant Industry, $\mathrm{n}^{\circ}$ bull. 92, Washington. IX pl., $112 \mathrm{p}$. http://www.archive.org/details/datevarietiesdat00kearrich

Khanamm, S., Sham, A., Bennetzen, J. L., and Aly, M. A. M. (2012). Analysis of molecular marker-based characterization and genetic variation in date palm (Phoenix dactylifera L.). Australian Journal of Crop Science 6(8): 1236-1244 http://www.cropj.com/khanam 6 8 8 2012_1236_1244.pdf.

Klee W. $\bar{G}$. (1883). Culture of the date. Government printing office, $24, n^{\circ}$ Department of Agriculture, Washington. 25 p. https://archive.org/ details/cultureofdate24klee

Kuhl, F. P., and Giardina, C. R. (1982). Elliptic Fourier features of a closed contour. Computer Graphics and Image Processing 18(3): 236-258.

Kuhlmann K.-P. (2013). The realm of "two deserts": Siwah Oasis between east and west. In Förster F., and Riemer H. (eds.), Desert Road Archaeology in Ancient Egypt and Beyond, Heinrich-Barth-Institut, Köln.

Ludeña B., Chabrillange N., Aberlenc-Bertossi F., Adam H., Tregear J. W., and Pintaud J.-C. (2011). Phylogenetic utility of the nuclear genes AGAMOUS 1 and PHYTOCHROME B in palms (Arecaceae): an example within Bactridinae. Annals of Botany 108(8): 1433-1444. https://doi.org/10.1093/aob/mcr191

Mathew L. S., Seidel M. A., George B., Mathew S., Spannagl M., Haberer G., Torres M. F., Al-Dous E. K., Al-Azwani E. K., Diboun I., Krueger R. R., Mayer K. F. X., Mohamoud Y. A., Suhre K., and Malek J. A. (2015). A Genome-Wide Survey of Date Palm Cultivars Supports Two Major Subpopulations in Phoenix dactylifera. G3: Genes|Genomes|Genetics 5(7): 14291438. https://doi.org/10.1534/g3.115.018341

McKey, D., Elias, M., Pujol, B., and Duputié, A. (2010). The evolutionary ecology of clonally propagated domesticated plants. New Phytologist 186: 318-332. http://onlinelibrary.wiley.com/. https:// doi.org/10.1111/j.1469-8137.2010.03210.x/full.

Michel-Dansac F., and Caubet A. (2013). L'iconographie et le symbolisme du palmier dattier dans l'Antiquité (Proche-Orient, Égypte, Méditerranée orientale). Revue d'ethnoécologie 4 (The Date Palm: Origin and Cultivation in the Middle East and in Egypt). http://ethnoecologie.revues.org/1275

Minutoli H. F. V. (1827). Nachträge zu meinem Werke betitelt: Reise zum Tempel des Jupiter Ammon in der libyschen Wüste, und nach OberAegypten in den Jahren 1820 und 1821. Maurerschen Buchhandlung, Berlin. 377 p. http://catalog.hathitrust.org/Record/ 008642413

Murray G. W. (1935). Sons of Ishmael, a study of the Egyptian Bedouin. G. Routledge \& Sons 1td, London. xxxi pl., 344 p. https://archive. org/details/sonsofihmaelastudyoftheegyptianbedouin

Nei, M., Tajima, F., and Tateno, Y. (1983). Accuracy of estimated phylogenetic trees from molecular data. II. Gene frequency data. Journal of Molecular Evolution 19(2): 153-170.

Pacho J. R. (1827). Relation d'un voyage dans la Marmarique, la Cyrénaïque et les oasis d'Audjelah et de Maradèh, accompagnée de cartes géographiques et topographiques et de planches présentant les monuments de ces contrées. Librairie de Firmin Didot père et fils, Paris. xxxix, 399 p. http://books.google.com/ books?id=h0N9XsUPbQwC

Pérau-Leroy P. (1958). Le palmier dattier au Maroc. Royaume du Maroc, ministère de l'Agriculture, service de la Recherche agronomique; Institut français de recherches fruitières outre-mer (IFAC), Mission au Maroc, s.l. 142 p.

Peyron G. (2000). Cultiver le palmier dattier. CIRAD, Guide illustré de formation, [Montpellier]. $110 \mathrm{p}$.

Peyron G., Gay F., and Rafat A. A. (1990). Phœnologie du palmier dattier. Contribution à l'étude du patrimoine génétique phœnicicole en Égypte. In Toutain G., and Dollé V. (eds.), Les systèmes agricoles oasiens, Actes du colloque de Tozeur (19-21 nov. 1988), CIHEAM, Montpellier. http://ressources.ciheam.org/om/pdf/a11/CI901489.pdf

Pintaud J.-C. (2010). Modèle de domestication et structure de l'agrobiodiversité du palmier dattier (Phoenix dactylifera L.). In Aberlenc-Bertossi F. (ed) Biotechnologies du palmier dattier, IRD éd., Paris. http://www.documentation.ird.fr/hor/fdi:010051490

Pintaud J.-C., Ludeña B., Aberlenc-Bertossi F., Zehdi S., GrosBalthazard M., Ivorra S., Terral J.-F., Newton C., Tengberg M., Abdoulkader S., Daher A., Nabil M., Saro Hernández I., González-Pérez M. A., Sosa P., Santoni S., Moussouni S., SiDehbi F., and Bouguedoura N. (2013). Biogeography of the date palm (Phoenix dactylifera L., Arecaceae): insights on the origin and on the structure of modern diversity. Acta horticulturae(994_1): 1938. https://www.researchgate.net/publication/257770248

Popenoe P. B., and Bennett C. L. (1913). Date growing in the old world and the new/by Paul B. Popenoe (with a chapter on the food value of the date). West India gardens, Altadena, Cal. 316 p. http://www. archive.org/details/dategrowinginold00poperich

R Core Team (2015). R: A language and environment for statistical computing. R Foundation for Statistical Computing, Vienna, Austria.P. https://www.r-project.org/

Racchi M. L., Bove A., Turchi A., Bashir G., Battaglia M., and Camussi A. (2013). Genetic characterization of Libyan date palm resources by microsatellite markers. 3 Biotech(February 2013): 1-12. https:// doi.org/10.1007/s13205-013-0116-6

Raffaillac J.-P., and Second G. (1997). Le manioc. In Charrier A., Jacquot M., Hamon S. et al. (eds.), L'amélioration des plantes tropicales, CIRAD; ORSTOM, Montpellier; Paris. http://www. documentation.ird.fr/hor/fdi:010012930

Rhouma A. (1994). Le palmier dattier en Tunisie, I. Le patrimoine génétique. Arabesques, INRA Tunisie, GRIDAO France, PNUD/ FAO, Tunis. 254 p.

Rhouma A. (2005). Le palmier dattier en Tunisie, I. Le patrimoine génétique, vol. 2. IPGRI, UNDP, GEF/FEM, Inrat Rome. 255 p. http://www.bioversityinternational.org/fileadmin/bioversity/ publications/pdfs/1113_Le_Palmier_Dattier_en_Tunisie.pdf

Riou C. (1990). Bioclimatologie des oasis. In Toutain G., and Dollé V. (eds.), Les systèmes agricoles oasiens, Actes du colloque de Tozeur (19-21 nov. 1988), CIHEAM, Montpellier. http://om.ciheam.org/ om/pdf/a11/CI901496.pdf

Rizk, S. A., and Rashed, N. A. K. (2005). Morphological and Genetical studies on some date palm cultivars and strains grown under Siwa Oasis conditions-Egypt. Minufiya Journal of Agricultural Research 30(4): 1233-1246.

Robecchi-Bricchetti L. (1890). All' oasi di Giove Ammone, viaggio di L. Robecchi-Bricchetti. Fratelli Treves, Editori, Milano. 3 pl., 374 p. http://access.bl.uk/item/viewer/lsidyv35073d0f

Roué, M., Battesti, V., Césard, N., and Simenel, R. (2015). Ethnoecology of pollination and pollinators: Knowledge and practice in three societies. Revue d'ethnoécologie 2015(7). https://doi.org/10.4000/ ethnoecologie. 2531

Rusch W., and Stein L. (1988). Siwa und die Aulad Ali: Darstellung und Analyse der sozialökonomischen, politischen und ethnischen Entwicklung der Bevèolkerung der westlichen Wüste Ægyptens 
und des Prozesses ihrer Integration in den Ægyptischen Staat von Beginn des 19. Jahrhunderts bis 1976. Akademie-Verlag, Verèoffentlichungen des Museums fèur Vèolkerkunde zu Leipzig, Heft 35, Berlin. 32 pl., 284 p.

Scholz J. M. A. (1822). Travels in the countries between Alexandria and Paraetonium, the Lybian Desert, Siwa, Egypt, Palestine, and Syria, in 1821. Sir Richard Phillips \& Co., London. iv, 120 p.

Second, G., Raffaillac, J.-P., and Colombo, C. (1999). Le manioc. In Hamon, P., Seguin, M., Perrier, X., et al. (eds.), Diversité génétique des plantes tropicales cultivées, CIRAD, Montpellier.

Siegal, M. L., and Bergman, A. (2002). Waddington's canalization revisited: Developmental stability and evolution. Proceedings of the National Academy of Sciences 99(16): 10528-10532.

Steindorff, G. (1904). Durch die libysche Wüste zur Amonsoase. Vertag von Velhagen und Klasing, Land und Leute, Monographien zur Erdkunde, $\mathrm{n}^{\circ}$ 19. Bielefeld und Leipzig. 3: 163. http://tinyurl. galegroup.com/tinyurl/3DcKo6.

Tengberg M. (2012). Beginnings and early history of date palm garden cultivation in the Middle East. Journal of Arid Environments 86 (Supplement C: November 2012, Ancient Agriculture in the Middle East): $139-147$

Terral J.-F., Newton C., Ivorra S., Gros-Balthazard M., de Morais C. T., Picq S., Tengberg M., and Pintaud J.-C. (2012). Insights into the historical biogeography of the date palm (Phoenix dactylifera L.) using geometric morphometry of modern and ancient seeds. Journal of Biogeography 39(5): 929-941
Wansleb J. M. (1794 [1664]). Beschreibung von Aegypten im Jahr 1664. In Paulus H. E. G. (ed) Sammlung der merkwürdigsten reisen in den Orient: In uebersezungen und auszügen mit ausgewälten kupfern und charten, auch mit den nöthigen einleitungen anmerkungen und kollectiven registern, Chrift Heinz. Cuno's Erben, Jena. https://archive.org/details/ sammlungdermerk10jesugoog

White A. S. (1899). From Sphinx to Oracle. Through the Libyan Desert to the Oasis of Jupiter Ammon. Hurst and Blackett, limited, London. xv. 277 p. http://tinyurl.galegroup.com/tinyurl/3Db4z0

Wilson, A. (2012). Saharan trade in the roman period: Short-, mediumand long-distance trade networks. Azania: Archaeological Research in Africa 47(4): 409-449.

Zaid, A., and Arias-Jiménez, E. J. (eds.) (1999). Date palm cultivation, plant production and protection paper, $\mathrm{n}^{\circ} 156, \mathrm{FAO}$, Rome.

Zehdi-Azouzi S., Cherif E., Moussouni S., Gros-Balthazard M., Abbas Naqvi S., Ludeña B., Castillo K., Chabrillange N., Bouguedoura N., Bennaceur M., Si-Dehbi F., Abdoulkader S., Daher A., Terral J.-F., Santoni S., Ballardini M., Mercuri A., Ben Salah M., Kadri K., Othmani A., Littardi C., Salhi-Hannachi A., Pintaud J.-C., and Aberlenc-Bertossi F. (2015). Genetic structure of the date palm (Phoenix dactylifera) in the Old World reveals a strong differentiation between eastern and western populations. Annals of Botany 116(1): 101-112. https://doi.org/10.1093/aob/mcv068 